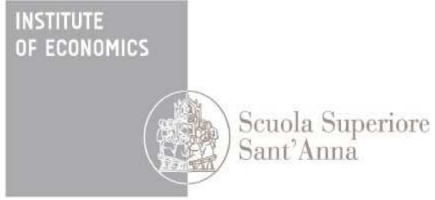

LEM | Laboratory of Economics and Management

Institute of Economics

Scuola Superiore Sant'Anna

Piazza Martiri della Libertà, 33 - 56127 Pisa, Italy ph. +3905088.33 .43$

institute.economics@sssup.it

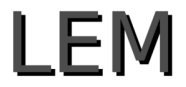

Working Paper Series

On the Stability of Euro Area Money Demand and its Implications for Monetary Policy

\author{
Matteo Barigozzi ${ }^{\S}$ \\ Antonio Conti *
}

${ }^{\S}$ London School of Economics, UK, and ECARES, Universite' Libre de Bruxelles, Belgium

*Bank of Italy, Territorial Economic Research Unit, and ECARES, Universite' Libre de Bruxelles, Belgium 


\title{
On the Stability of Euro Area Money Demand AND ITS IMPLICATIONS FOR MONETARY POLICY
}

\author{
Matteo BARIGOzZI ${ }^{\dagger \ddagger} \quad$ Antonio ConTI* ${ }^{*}$
}

April 26, 2013

\begin{abstract}
We revisit the usefulness of long-run money demand equations for the European Central Bank. We first conduct a model evaluation exercise by means of a recent time-varying cointegration test. A stable relation for euro area M3 is not rejected by data only when accounting for both a speculative motive, represented by international financial markets, and a precautionary motive, proxied by changes in the unemployment rate. Second, relying on this finding, we propose and estimate a novel time-invariant specification for money demand which allows us $(i)$ to build a leading indicator of stock market busts and (ii) to describe the anomalous behavior of M3 in the last decade. Excess liquidity matters for both financial and price stability.
\end{abstract}

JEL Classification: E41, E52, C32

Keywords: money demand; time-varying cointegration; price-earnings ratios; unemployment rate; monetary policy.

$\dagger$ London School of Economics and Political Science, United Kingdom;

* Bank of Italy, Territorial Economic Research Unit, Italy;

¥ ECARES, Université libre de Bruxelles, Belgium.

Corresponding author: Antonio M. Conti, E-mail: antoniomaria.conti@bancaditalia.it.

The views here expressed are those of the authors and do not reflect those of the Bank of Italy. 


\section{Introduction}

The Great Financial Crisis of 2007-2009 has brought back the attention to the role of money in macroeconomics (see, among others, Adrian and Shin, 2009; Bordo and Haubrich, 2010). Indeed, during the last three decades two related factors led to the gradual disappearing of money from monetary analysis, up to the point that scholars asked what would have been the future of monetary aggregates in monetary policy (Nelson, 2003). First, it emerged and was established a new paradigm in modern macroeconomics, the New Keynesian model, in which the short-term interest rate is the instrument assigned to the mandate of controlling inflation (Woodford, 2003; Galí, 2008). Second, and tied to the former, the estimates of money demand equations became unstable with a consequent breakdown of the quantity theory (see, e.g. Ball, 2001; Teles and Uhlig, 2010; Sargent and Surico, 2011).

On the other hand, a number of contributions has presented evidence at odds with the irrelevance of money. Nelson (2002) and Favara and Giordani (2009) highlight direct effects of money in the business cycle, and, consistently, money is found to have an incremental predictive content for output (Hafer et al., 2007) and inflation (Nelson, 2008). Furthermore, Reynard (2007) reveals the pitfalls of pursuing a low inflation target without monitoring monetary aggregates, while Beck and Wieland (2008) show the benefits of monetary crosschecking with respect to achieving price stability.

In this paper, we reconsider the usefulness of long-run money demand equations for the European Central Bank (ECB). In particular, we are interested in assessing whether money demand may help in signaling financial imbalances. The choice of the ECB looks appropriate for this exercise due to the prominent role attached to monetary aggregates in its two pillars strategy. Since 1999 the ECB has started to monitor the growth rate of the euro area (EA) broad monetary aggregate M3, deeming a value of $4.5 \%$ consistent with the statutory objective of inflation close but below to $2 \%$. This is known as the monetary pillar, which complements the economic pillar, centered around developments in output, prices and cost indicators. Although inflation has been kept under control, since 2001 M3 growth rate has begun to diverge from its reference value (see figure 1). At the same time signs of instability in EA money demand has been detected since the introduction of the euro. This anomalous behaviour of M3 contributed to the criticism of the monetary pillar which eventually led to its downgrading in the ECB monetary policy strategy (European Central Bank, 2003; Galí, 2010). ${ }^{1}$

Despite these drawbacks, the ECB has continued to inspire and promote research on the causes of the instability of the demand for M3. ${ }^{2}$ Beyond the transactional and the opportunity cost motives for holding money (Calza et al., 2001; Coenen and Vega, 2001; Gerlach and Svensson, 2003; Vlaar, 2004), new motives have been proposed in recent years. Carstensen (2006) and De Santis et al. (2012) consider EA and international financial markets respectively, Beyer (2009) and Dreger and Wolters (2010b) propose housing wealth, while De Bondt (2010) introduces changes in unemployment as a precautionary motive. All these authors claim to find a stable money demand equation. However, there is no consensus on the determinants of

\footnotetext{
${ }^{1}$ The necessity of a separate monetary pillar has been widely investigated by Rudebusch and Svensson (2002); Gerlach and Svensson (2003); Gerlach (2004) among others, and often criticized (Woodford, 2007, 2008).

${ }^{2}$ While also the dynamics of M1 could be of interest, M3 is the reference monetary aggregate. By consequence, following the literature, we focus on the demand of M3.
} 
M3 and, by consequence, policy implications remain unclear. ${ }^{3}$

While the evidence points towards the emergence of anomalies in money demand in the early 2000s, the exact date of such break remains however unknown. ${ }^{4}$ We therefore investigate the existence of a stable long-run money demand equation in the EA by using the time-varying cointegration framework recently proposed by Bierens and Martins (2010). In particular, this approach allows for a smooth evolution of long-run parameters, thus avoiding the need of specifying the exact timing of the structural break. By means of this methodology, we perform a model evaluation exercise, aimed at testing for parameter time invariance in the main specifications for money demand proposed by the literature and previously cited. Results show that the majority of the considered models are unstable after 2001. We find however two exceptions when including $(i)$ the spread between EA and US price-earnings ratios, considered as a speculative motive by De Santis et al. (2012), and (ii) the changes in EA unemployment rate, used as a proxy of a precautionary motive by De Bondt (2010).

We then develop further this argument by proposing a new stable model for money demand which relies on both motives. Indeed, once stability is ensured, since the standard cointegration methodology by Johansen (1996) is a particular case of the most general timevarying cointegration framework by Bierens and Martins (2010), we can specify a cointegrated VAR model where the standard money demand specification, containing income, inflation, and interest rates, is augmented with the two new variables: the spread between EA and US priceearnings ratios and changes in the EA unemployment rate. We find that: $(i)$ a meaningful money demand equation is identified among the three cointegration relations present in our model; ( $i i)$ both the speculative and the precautionary motive are strongly relevant to describe M3 dynamics; ( $i i i)$ the new model is stable according to the Bierens and Martins (2010) test, for each time span and cointegration rank considered; $(i v)$ the monetary overhang computed from our model is a leading indicator of the probability of a stock market bust and a relevant predictor of inflation; $(v)$ our model helps in predicting M3 growth in EA during the Great Financial Crisis, from 2009:Q1 to 2010:Q4.

The contribution of this paper is therefore twofold. First, we provide a model evaluation exercise among different models, hence filling a gap in the literature on EA money demand. Second, we add to the increasing debate on central banks financial stability mandate suggesting that information stemming from the monetary pillar and, in particular, from excess liquidity measures, may help the ECB in predicting stock market busts.

The rest of the paper is organized as follows. Section 2 reviews the modeling strategy for long-run money demand equations and surveys the literature on the EA. Section 3 briefly describes the time-varying cointegration test by Bierens and Martins (2010), while section 4 presents the results of the test. Section 5 proposes a new stable dynamic model of money demand, unemployment, and stock markets, while section 6 discusses the policy implications of this model for the ECB. In section 7 we conclude. In the appendix we provide the description of the data used and additional estimation results. Finally, plots of the data, robustness analysis relative to the Bierens and Martins (2010) test and the estimation of the cointegrated VAR model, together with other complementary results are available online from the first

\footnotetext{
${ }^{3}$ Other contributions not evaluated in this paper are, among others, Funke (2001); Bruggemann et al. (2003); Artis and Beyer (2004); Brand and Cassola (2004); Setzer et al. (2011). They adopt, however, very similar specifications to the aforementioned.

${ }^{4}$ For example, Weber et al. (2011) identify a change in the monetary transmission mechanism in the EA in 1996.
} 
author's webpage. ${ }^{5}$

\section{Modeling euro area money demand}

Classical modeling. Economic theory assumes the quantity of real money holdings to be a function $f$ of the amount of transactions in the economy, the so called transactional motive, approximated by income $Y_{t}$ or other scale variables such as wealth, and of a set of explanatory variables $\mathbf{X}_{t}$ representing either the opportunity cost of holding money or other possible motives:

$$
\frac{M_{t}}{P_{t}}=f\left(Y_{t}, \mathbf{X}_{t}\right),
$$

where $M_{t}$ denotes the nominal monetary aggregate, typically M3 when analyzing the EA, and $P_{t}$ is the aggregate price level. The function $f(\cdot, \cdot)$ usually takes a log-linear or a semi-loglinear form, while $\mathbf{X}_{t}$, for example, may include the own rate of money, i.e. the return of the less liquid assets contained in M3, the short-term interest rate (the policy instrument), and inflation. Since a proper characterization of the vector $\mathbf{X}_{t}$ is crucial for estimating (1), one of the aims of this paper is precisely to evaluate the possible choices of $\mathbf{X}_{t}$ propose by some of the most influential specifications of money demand for the EA (see Golinelli and Pastorello, 2002; De Bondt, 2010; Papademos and Stark, 2010, for surveys on different specifications in literature).

Consistently with the fact that both $\log \left(M_{t} / P_{t}\right) \equiv\left(m_{t}-p_{t}\right)$ and $\log Y_{t} \equiv y_{t}$ display a unit root, i.e. are $I(1)$ processes, the empirical literature on money demand concerns the estimation of a semi log-linear form of the long-run relation (1) and it is based on cointegration techniques as in Stock and Watson (1993) or Johansen (1996). In this paper we adopt the latter approach and we consider the following Vector Error Correction model (VECM) for $\mathbf{Z}_{t}=\left[\left(m_{t}-p_{t}\right) y_{t} \mathbf{X}_{t}\right]^{\prime}$

$$
\Delta \mathbf{Z}_{t}=\gamma_{0}+\boldsymbol{\Pi} \mathbf{Z}_{t-1}+\sum_{j=1}^{p-1} \boldsymbol{\Gamma}_{j} \Delta \mathbf{Z}_{t-j}+\varepsilon_{t}, \quad \varepsilon_{t} \stackrel{\text { i.i.d. }}{\sim} \mathrm{N}_{k}(\mathbf{0}, \boldsymbol{\Omega}), \quad t=1, \ldots, T,
$$

where $T$ is the number of observations, $k$ is the dimension of $\mathbf{Z}_{t}, \boldsymbol{\Omega}$ is the $k \times k$ variancecovariance matrix of the errors $\varepsilon_{t}$, and $\boldsymbol{\Gamma}_{j}$ are $k \times k$ matrices. If variables are cointegrated, we can write $\boldsymbol{\Pi}=\boldsymbol{\alpha} \boldsymbol{\beta}^{\prime}$ where $\boldsymbol{\alpha}$ and $\boldsymbol{\beta}$ are fixed $k \times r$ matrices with reduced rank $r<k$ equal to the number of cointegration vectors. If $r=1$, the long-run money demand equation is then given by the vector $\boldsymbol{\beta}^{\prime} \mathbf{Z}_{t-1}$. However, in principle, we cannot exclude the presence of more than one cointegrating relation, i.e. $r \geq 1$, like, say, the Fisher Interest Parity and the expectations theory (Coenen and Vega, 2001; Vlaar, 2004). In this last case, restrictions must be imposed in order to identify the long-run money demand equation among the $r$ estimated.

Defining instability. The long-run EA money demand equation has been studied by Calza et al. (2001), Coenen and Vega (2001), Gerlach and Svensson (2003), and Vlaar (2004) among others when analyzing data up to 2001. However, when including also data after 2001, these specifications are likely to fail in delivering a stable relation for money demand. Instability can be detected for example when considering the cointegration residual of the money demand equation, i.e. the monetary overhang, which represents the distance of actual M3 from its

\footnotetext{
${ }^{5}$ http://www . barigozzi.eu/
} 
long-run equilibrium (e.g see figure 2.a). After 2001 this series is no more mean reverting, thus suggesting the presence of some structural change in the parameters of the model. More recent works claim to solve the stability problem by adding a variety of new variables related to financial, housing, or labor markets to the vector $\mathbf{X}_{t}$ (see e.g. Carstensen, 2006; Beyer, 2009; Dreger and Wolters, 2010a,b; De Bondt, 2010; De Santis et al., 2012). Indeed, figure 2.b-2.d show a more stable behavior for the money demand residual when adding new explanatory variables.

More precisely, the standard way of quantifying instability is based on a recursive estimation of the preferred model and on the related tests for stability of the estimated parameters (for a detailed description of this procedure, see, for example, Juselius, 2006). These recursive procedures add further evidence to instability after 2001, thus urging the search for new motives for holding money. In fact, when these tests are computed on the novel specifications such as the ones including financial or housing variables (De Santis et al., 2012; Beyer, 2009; Dreger and Wolters, 2010b) stability is no more rejected. However, since each of the latter specification proposes a different money demand equation, the related policy implications remain unclear.

Assessing stability over time of the money demand equation could concern two different sets of parameters: (i) the long-run coefficients $\boldsymbol{\beta}$; (ii) the short-run coefficients $\boldsymbol{\alpha}$. Based on the fact that, according to the above mentioned literature, the former seem to be the most unstable, we take as given short-run dynamics stability, while, following the new methodology by Bierens and Martins (2010), we allow for a smooth evolution over time of the parameters $\boldsymbol{\beta}$. By adopting this approach the estimation of the long-run coefficients is no more recursive, but based on the whole sample considered. We therefore define stability of EA money demand as constancy over time of the parameters $\boldsymbol{\beta}$ governing the long-run equation for real balances. ${ }^{6}$

In particular, since the framework adopted by Bierens and Martins (2010) nests the usual time-invariant VECM, the econometric methodology we adopt encompasses standard estimation techniques used by the literature. Therefore, differently from the recursive approach, the choice of the time-varying cointegration test allows us to study and select, among different candidates, those determinants of money demand in the EA able to deliver a stable specification (if any). In this sense we are performing a model evaluation and selection exercise similar to the Encompassing test principle by Mizon and Richard (1986) rather than just a test of structural change in the parameters.

Before presenting the details on the methodology and the results of the test, let us briefly summarize the evaluated models.

Literature review. Our starting point is the benchmark model for money demand by Calza et al. (2001):

$$
\left(m_{t}-p_{t}\right)=\beta_{0}+\beta^{y} y_{t}+\beta^{s-o}\left(s_{t}-o_{t}\right)+\beta^{\ell-o}\left(\ell_{t}-o_{t}\right),
$$

where $\left(m_{t}-p_{t}\right)$ is the log of real balances, $y_{t}$ is the log of real GDP, $s_{t}$ and $\ell_{t}$ represent the short and long term interest rates respectively, and $o_{t}$ stands for the own rate of M3. Model (3) has been used in the Quarterly Monetary Assessment by ECB during the period 20012006 (see also Fischer et al., 2009). Similar specifications are also considered by Coenen and Vega (2001), Gerlach and Svensson (2003), and Vlaar (2004). In all these works real balances

\footnotetext{
${ }^{6}$ A broader definition, not considered in this paper, would be based on the possibility of identifying a stable long-run relation between money growth and inflation, in the spirit of the quantity theory (see, for example, Sargent and Surico, 2011).
} 
depend on real GDP and different combinations of the interest rates or their spreads, while Dreger and Wolters (2010a) add also for inflation $\pi_{t}$. We jointly refer to all these models as to classical specifications. As said above, in all these cases the disequilibrium path is found to be no more mean reverting after 2001 and moreover, the estimated coefficients of output and the short-term spread become unstable from 2003 onwards, with no additional benefit from allowing for a linear trend to capture velocity shift (see Beyer, 2009).

Carstensen (2006) is the first author to introduce new variables with respect to the classical set in order evaluate the concern that excess of liquidity in the EA might fuel inflation. Specifically, he argues that high money growth observed since 2001 may derive from neglecting the stock market impact when estimating money demand equations. His view is empirically supported by the fact that shifts from risky assets to funds in M3 represent a large fraction of excess of money growth (European Central Bank, 2003). He thus proposes to augment the classical model of money holdings to account for the effect of financial variables, proxied by equity returns $\Delta e_{t}$ and stock market volatility $v_{t}$.

De Santis et al. (2012) propose an international portfolio allocation approach based on the assumption of wealth diversification among money, domestic and foreign risky assets. After observing that cross-border portfolio flows may explain recent monetary developments in the EA, they augment the classical set of explanatory variables with price-earnings ratios, $q_{t}$ and $q_{t}^{*}$, as proxies of Sharpe ratios in the EA and US markets, and EA and US long term interest rates.

Beyer (2009) emphasizes the role of housing wealth in capturing the trending behaviour of money in the first ten years of ECB existence. He finds a stable specification when adding to the classical opportunity cost variables the quarterly growth rate of housing wealth, $\Delta h_{t}$, as a further scale variable to real GDP.

De Bondt (2010) focuses on the role of equity and labor markets. He finds evidence of a stable money demand equation when including in the opportunity cost vector wealth, $w_{t}$, equity returns, $\Delta e_{t}$, and annual changes in the unemployment rate $\Delta u_{t}$, thus highlighting the importance of the financial channel and the existence of a novel precautionary motive. The first effect can be decoupled in a positive one coming from wealth and a negative one deriving from expected equity returns. The second effect is less standard and represents a precautionary saving motive: money is hoarded when labor market weakens, i.e. when the unemployment rate rises. ${ }^{7}$ An improvement in labor markets conditions, normally associated to a higher GDP and, thus, to a higher demand for real balances, also lowers long-run precautionary demand for money.

Finally, Dreger and Wolters (2010b) add to their original specification, with just interest rates and inflation, a measure of real financial wealth $f_{t}$, which is proxied by real house prices. They further develop their argument analyzing the relation between money and inflation in the Great Financial Crisis (Dreger and Wolters, 2011).

In table 1 we summarize all the specifications considered in this paper, together with the opportunity cosr variables $\mathbf{X}_{t}$, the cointegration rank $r$, and the time sample as given in the original reference.

\footnotetext{
${ }^{7}$ Moreover, the annual change in unemployment is strongly correlated with consumer confidence sentiment (see De Bondt, 2010).
} 


\section{Time-varying cointegration}

We briefly present here the test proposed by Bierens and Martins (2010) for the null-hypothesis of time-invariance of cointegrating relations. The starting point is the time-varying VECM of order $p$ :

$$
\Delta \mathbf{Z}_{t}=\gamma_{0}+\boldsymbol{\alpha} \boldsymbol{\beta}_{t}^{\prime} \mathbf{Z}_{t-1}+\sum_{j=1}^{p-1} \boldsymbol{\Gamma}_{j} \Delta \mathbf{Z}_{t-j}+\varepsilon_{t}, \quad \varepsilon_{t} \stackrel{\text { i.i.d. }}{\sim} \mathrm{N}_{k}(\mathbf{0}, \boldsymbol{\Omega}), \quad t=1, \ldots, T .
$$

where the only difference with respect to the time-invariant model (2) is in the time dependence of the long-run coefficients $\boldsymbol{\beta}_{t}$. It is possible to prove that $\boldsymbol{\beta}_{t}$ can be approximated by a finite sum of Chebyshev polynomials $P_{h, T}(t)$ of decreasing smoothness:

$$
\boldsymbol{\beta}_{t}=\sum_{h=0}^{m} \boldsymbol{\xi}_{h} P_{h, T}(t), \quad P_{h, T}(t)=\sqrt{2} \cos \left(h \pi \frac{t-0.5}{T}\right), \quad h \geq 0, \quad t=1, \ldots T,
$$

where $m=1, \ldots, T-1$ and $\boldsymbol{\xi}_{h}$ are $k \times r$ matrices (see the appendix for details).

By substituting (5) into (4), we get

$$
\Delta \mathbf{Z}_{t}=\gamma_{0}+\boldsymbol{\alpha}\left(\sum_{h=0}^{m} \boldsymbol{\xi}_{h} P_{h, T}(t)\right)^{\prime} \mathbf{Z}_{t-1}+\sum_{j=1}^{p-1} \boldsymbol{\Gamma}_{j} \Delta \mathbf{Z}_{t-j}+\varepsilon_{t}
$$

Therefore, since $P_{0, T}(t)=1$, when $m=0$, the time-varying VECM (6) becomes the timeinvariant VECM (2). We are interested in testing the null-hypothesis $m=0$, or, equivalently, $\boldsymbol{\beta}_{t}=\boldsymbol{\xi}_{0}$, of a time-invariant cointegration against the alternative hypothesis $m>0$ of time-varying cointegration. The two cases are therefore nested and both (2) and (6) can be estimated by maximum likelihood. Consequently a likelihood ratio test for the null-hypothesis of time-invariant cointegration, i.e. $m=0$, emerges naturally as

$$
L R_{T}=2\left[\hat{\ell}_{T}(r, m>0)-\hat{\ell}_{T}(r, m=0)\right],
$$

where $\hat{\ell}_{T}(r, \cdot)$ are the sample Gaussian log-likelihoods computed in the estimated values of the parameters. In both cases $r$ is the cointegration rank. Bierens and Martins (2010) prove in Theorem 1 of their paper that, as $T \rightarrow \infty$, the statistics $L R_{T}$ is distributed as $\chi_{(r m k)}^{2}$. They also compute empirical critical values via Monte Carlo simulations and show that already for $T=100$ these values are very close to the asymptotic critical values. Since we here consider quarterly data from 1980:Q1 to 2008:Q4, i.e. $T=116$, we compute $p$-values of the test based on the asymptotic distribution and its quantiles. ${ }^{8}$

\section{Testing for stability}

In this section, we first briefly discuss the data used and the setup for the Bierens and Martins (2010) methodology, and we then present the results of the likelihood ratio test $L R_{T}$ for the null-hypothesis of time-invariant cointegration when applied to the specifications presented in

\footnotetext{
${ }^{8} \mathrm{~A}$ similar approach is in Park and Hahn (1999), while for a Bayesian perspective on time-varying cointegration, which we do not consider here, see e.g. Koop et al. (2011).
} 
section 2 .

Data and setup. We use quarterly data covering the period 1980:Q1-2010:Q4. In order to have a consistent dataset, and to avoid problems due to revisions and extensions of the original datasets used in the literature, whenever possible we take data from the Area Wide Model dataset (Fagan et al., 2001) or from the ECB data warehouse. Indeed, the former is the standard source for empirical studies on the EA (Smets and Wouters, 2003), while the latter is the most reliable source for financial data. ${ }^{9}$

Few other remarks are necessary. First, the likelihood ratio test is computed just for the case $m=1$, i.e. when allowing for just the first Chebyshev polynomial as source of time variation. From (5), we notice that $m=1$ corresponds to the slowest time-varying effect and moreover to the only monotonic change in the level of the coefficients (see also the appendix). Both features are supported by previous studies where a slow change in the long-run money demand equation is observed, a behavior which in turn is mainly due to an upward shift in income elasticity as shown in Dreger and Wolters (2010b). Second, we report results for four different samples, all starting in 1980:Q1 and ending in: 2001:Q4, i.e. before euro introduction, in 2007:Q4, i.e. before the recent Financial Crisis, and in 2008:Q4 and 2009:Q4, i.e. including the most recent available data. We consider as our baseline sample the one ending in 2008:04, in order to use data covering 2009 and 2010 for the prediction exercise described in section 6 . Third, we show here only results for the number of lags in equation (4), i.e. $p=2$. Results for $p=1,3$ are qualitatively similar. Finally, since no cointegration rank test is available in the time-varying framework by Bierens and Martins (2010), the whole procedure is repeated for the cointegration rank $r=1,2$, and 3, thus including all the values of $r$ considered in the literature and reported in table 1.

Results. We test all specifications presented in section 2 and summarized in table 1 and we present the results in tables 2 to 4 . In each table, we report the $L R_{T}$ statistics together with its corresponding $p$-value for the nul-hypothesis of no time variation, jointly with the reference to the original work considered, and the vector $\mathbf{X}_{t}$. We show results for each of the samples and cointegration rank considered.

Table 2 is related to the four classical models by Calza et al. (2001), Coenen and Vega (2001), Gerlach and Svensson (2003), and Vlaar (2004), taken as the starting point of the analysis. While the first two models are time-varying on all samples considered, the last two have large $p$-values on the pre-euro sample, consistently with the finding documented in these papers of a stable money demand equation before 2001. However, when extending the estimation sample up to 2007:Q4 and the following years, we reject the time-invariant null-hypothesis for all classical specifications.

Table 3 presents results for those specifications claiming to find a stable relation once extending the set of explanatory variables to new motives related to financial and housing markets (Carstensen, 2006; Beyer, 2009; Dreger and Wolters, 2010a,b). Although when considering data until 2001:Q4 in most cases we cannot reject the null-hypothesis of time-invariant cointegration, instability is always observed when extending the sample to the most recent years. This finding suggests the need for looking for other explanatory variables able to explain a time-invariant long-run money demand equation.

Indeed, we gain more insights on the determinants of money demand when we consider

\footnotetext{
${ }^{9}$ For a detailed description of the dataset, see the appendix.
} 
table 4, where we report the values of the test for those models based on labor markets (De Bondt, 2010) and international financial markets (De Santis et al., 2012). In the majority of the considered cases, the hypothesis of time-invariant cointegration is accepted also when including data relative to the most recent years. In particular, results shown in table 4 suggest a major role as explanatory variables of a time-invariant money demand equation for the annual changes in unemployment $\left(\Delta u_{t}\right)$ as defined in De Bondt (2010), and for the price-earnings ratios of EA and US $\left(q_{t}\right.$ and $\left.q_{t}^{*}\right)$ as defined in De Santis et al. (2012). However, although promising, these results only hold if we limit ourselves to the case $r=1$. This limitation poses problems of interpretation as the specifications considered have usually more than one cointegrating relation, namely $r=1$ or 2 in De Bondt (2010), while $r=3$ in De Santis et al. (2012).

The results of this section help us in discriminating among the possible explanatory variables of money demand used in the literature, but do not provide a definitive answer to our main question: which are the crucial determinants (if any) for observing a time-invariant long-run money demand equation in the EA?

\section{Money, international stock markets and unemployment}

Starting from the results in table 4 , in this section we set-up a time-invariant cointegrated VAR (CVAR) model accounting for different motives for holding money. We propose a specification including income $y_{t}$ proxied by real GDP, price-earnings ratios of both EA and US ( $q_{t}$ and $q_{t}^{*}$ respectively), the annual change in the unemployment rate $\left(\Delta u_{t}\right)$, the quarterly inflation rate $\left(\pi_{t}\right)$, and the interest rates, namely the long-term rate $\left(\ell_{t}\right)$ and the own rate $\left(o_{t}\right)$ of M3. ${ }^{10} \mathrm{We}$ thus estimate the following model:

$$
\Delta \mathbf{Z}_{t}=\gamma_{0}+\boldsymbol{\alpha} \boldsymbol{\beta}^{\prime} \mathbf{Z}_{t-1}+\sum_{j=1}^{p-1} \boldsymbol{\Gamma}_{j} \Delta \mathbf{Z}_{t-j}+\varepsilon_{t}, \quad \varepsilon_{t} \stackrel{\text { i.i.d. }}{\sim} \mathrm{N}_{k}(\mathbf{0}, \boldsymbol{\Omega}), \quad t=1, \ldots, T,
$$

where $\mathbf{Z}_{t}=\left[\begin{array}{llllll}\left(m_{t}-p_{t}\right) & y_{t} & \Delta u_{t} & \left(q_{t}-q_{t}^{*}\right) & \left(\ell_{t}-o_{t}\right) & \pi_{t}\end{array}\right]^{\prime}$. In the estimation we consider an unrestricted constant, thus allowing for an intercept in the cointegration space and for trending variables, but not for a trend in the cointegrating vectors. ${ }^{11}$

We set the spread between price-earnings ratios and between long interest rate and the return on M3 to have unit coefficients since both restrictions are strongly supported by data. The size of the model is $k=6$, and we comment here only the results for the sample 1980:Q12008:Q4, i.e. $T=116$, and when using two lags in the VAR, i.e. $p=2$. The time-varying cointegration test by Bierens and Martins (2010) on this model accepts the null-hypothesis of a time-invariant cointegration relation with rank $r=1,2$, and 3 thus justifying the time-

\footnotetext{
${ }^{10}$ We also experimented with the short-term rate instead of the own rate of money, but results are substantially identical because of the high correlation between the two (De Santis et al., 2012; Giannone et al., 2012). Moreover, other specifications including housing market variables were tested but found to be unstable. Results are available in the appendix.

${ }^{11}$ To be as consistent as possible with the framework proposed by Bierens and Martins (2010), we do not include any trend in the cointegrating space nor any dummy variable which could account for anomalous values in M3 growth rate (see, e.g., Dreger and Wolters, 2010b). Indeed, presently the $L R_{T}$ test by Bierens and Martins (2010) is available for the drift case only. As a major check, when estimating model (8) allowing for the trend in cointegration space, results are totally unaffected, as the exclusion of the trend from the system can not be rejected by the test $\chi_{(6)}^{2}=6.177$, with a corresponding $p$-value of 0.52 .
} 
invariant approach (see table 5). ${ }^{12}$ In particular, according to the Johansen trace test, the hypothesis of three cointegrating vectors can not be rejected at the $10 \%$ and we thus select $r=3$ (see table 6 ). Finally, the standard battery of diagnostics tests reported in the appendix confirms the goodness of fit of our specification.

Long-run structure. We identify the three cointegrating relations as: $(i)$ a long-run money demand equation, (ii) an aggregate demand equation, and (iii) a relation between the yield curve and inflation. Table 7 presents the restricted estimates of the long-run coefficients, $\widehat{\boldsymbol{\beta}}$. The likelihood ratio test for restrictions is distributed as $\chi_{(4)}^{2}$, and is equal to 3.737, giving a $p$-value of 0.44 , thus easily accepting the imposed restrictions.

Our focus is in particular on the long-run money demand equation which is given by ( $t$-statistics in parenthesis):

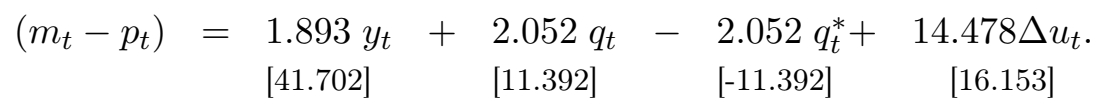

All the estimated parameters are strongly significant and display the expected sign. Real money holdings are a positive function of income, with a coefficient slightly lower than 2 , consistently with the wealth effect found by the literature (De Santis et al., 2012; Dreger and Wolters, 2010b). Also, they increase with the annual change of unemployment, which represents the precautionary motive and reflecting the uncertainty about the state of the economy. Finally, real balances increase with the spread between EA and US price-earnings ratios, i.e. the speculative motive. Thus, an increase in the relative convenience of EA assets produces a higher demand of euro from abroad, a finding consistent with the idea of a consolidation of the euro as reserve currency, which would explain the emergence of the speculative motive only after 2001. The cointegration residual of the money demand equation (9) or monetary overhang, defined as $\widehat{\eta}_{1, t}=\widehat{\boldsymbol{\beta}}_{1}^{\prime} \mathbf{Z}_{t}$, is shown in figure 3 and we observe the expected mean reverting behavior, which qualitatively proves the goodness of fit of our model and its stability.

Few remarks regarding the other two cointegrating vectors are necessary. Firstly, $\widehat{\boldsymbol{\beta}}_{2}$ displays a long-run relation between the interest rates spread and the change in unemployment. This is a long-run aggregate demand equation in which unemployment is linked to the slope of the yield curve, i.e. to $\left(\ell_{t}-o_{t}\right)$. Secondly, $\widehat{\boldsymbol{\beta}}_{3}$ represents the link between the yield curve and inflation. This latter relation somewhat differs from the standard Fisher Interest Parity observed, among others, in Coenen and Vega (2001) and Vlaar (2004) on samples ending before the launch of the euro. The rationale for such a long-run equation is that the yield curve is a relevant predictor of inflation. Among others, we refer to Estrella (2005), who shows that if monetary policy is essentially reactive to deviations of inflation from target and of output from potential, the predictive relationships for prices depend primarily on the magnitudes of the reaction parameters. Furthermore, similar relations for US economy are found for example in Beyer and Farmer (2007). Although beyond the scope of this paper, which focuses on money demand, a deeper analysis of the last two cointegrating relations could give some useful insights on the sacrifice ratio and the natural rate of unemployment in the EA, additionally helping for a careful inclusion of the yield curve in a macroeconomic model.

Short-run dynamics. Moving to the short-run dynamics, panel (a) of table 8 shows that most variables respond to the three disequilibria $\widehat{\eta}_{1, t}, \widehat{\eta}_{2, t}$, and $\widehat{\eta}_{3, t}$. In particular, money is

\footnotetext{
${ }^{12}$ We also run the usual recursive tests on stability of the parameters and all results support the stability of the considered model.
} 
strongly error correcting with respect to the second and the third cointegration relation $\left(\widehat{\alpha}_{12}\right.$ and $\widehat{\alpha}_{13}$ ), whereas the feedback coefficient obtained for the disequilibrium in money holdings $\left(\widehat{\alpha}_{11}\right)$ has the expected negative sign, but is not statistically different from zero. This result is also found by Beyer (2009), and requires a deeper analysis.

To study the role of money in the short-run, we first constrain to zero the coefficient of $\left(m_{t}-p_{t}\right)$, thus imposing the normalization on $y_{t}$. The $\chi_{(7)}^{2}$ test of exclusion of money has a value of 43.893 which strongly rejects money redundancy at $1 \%$ level. Second, we test the hypothesis $\alpha_{11}=\alpha_{12}=\alpha_{13}=0$ to assess the possibility of real balances not reacting to any of the estimated cointegration equations, hence being weakly exogenous: again, the test rejects the hypothesis at $1 \%$ level, with $\chi_{(7)}^{2}=19.746$. Moreover, as in Beyer (2009), we re-estimate the CVAR model with fixed values for $\widehat{\boldsymbol{\beta}}$, as given in (9), and by iteratively erasing nonsignificant variables, i.e. fixing at zero the correspondent elements of $\widehat{\Gamma}_{h}$ in (8). Results are reported in panel (b) of table 8 and we find a small but highly significant coefficient for the error correction term of money. Finally, as proved in Fanelli and Paruolo (2010), $\widehat{\alpha}_{11}$ only represents the instantaneous adjustment, while by following Pesaran and Shin (1998) we can consider the adjustment at different horizons by estimating the generalized impulse response of real balances to $\widehat{\eta}_{1, t}$. The result, obtained from a VAR as in King et al. (1991), is in figure 4.a and confirms a significant negative reaction at all considered lags.

When considering other variables, income is strongly error-correcting with respect to both the first and the second cointegration vector $\left(\widehat{\alpha}_{21}\right.$ and $\left.\widehat{\alpha}_{22}\right)$, i.e. the money demand equation and the aggregate demand relation. Unemployment is pulled away from its equilibrium with respect to changes in money demand $\left(\widehat{\alpha}_{31}\right)$, while the spread between the long-term rate and the own rate of M3 is adjusting to disequilibrium in the third relation $\left(\widehat{\alpha}_{53}\right)$, the one between interest rates and inflation. Last, inflation seems not error-correcting in neither of the above relations. Notice, however, that $\widehat{\alpha}_{61}$ is positive and significant, meaning that inflation is pushed up by deviation of real balances from their long-run equilibrium, hence suggesting that $\widehat{\eta}_{1, t}$ is a more reliable indicator for the effectiveness of the monetary pillar. This latter finding is also confirmed when considering the generalized impulse response of inflation to money disequilibrium, shown in figure 4.b.

\section{$6 \quad$ Money demand and monetary policy}

In this last section, we evaluate the usefulness of our estimates for policy makers. We consider three related topics: $(i)$ the role of long-run money demand in policies oriented to financial stability, (ii) the impact of excess liquidity on inflation, (iii) the performance of our model in predicting M3 and GDP growth rates.

Financial stability. The recent Great Financial crisis has triggered an increasing debate on the central bank mandate with respect to the pursue of financial stability joint to price stability (see, for example, Borio, 2006; Buiter, 2012, and references therein). In this first exercise, we build a binary indicator of stock prices busts, $B_{t}$, and we compare different explanatory variables for the probability of a bust at time $t$, i.e. for $p_{t} \equiv \operatorname{Prob}\left(B_{t}=1\right)$. Using data from 1980:Q1 to 2008:Q4, we build $B_{t}$ similarly to Gerdesmeier et al. (2010). First, we compute a composite financial market activity indicator $\Delta C_{t}$ obtained as the weighted average of equity quarterly growth rate $\Delta\left(\log E_{t}\right)$ and of house prices quarterly growth rate 
$\Delta\left(\log F_{t}\right):^{13}$

$$
\Delta C_{t}=\Delta\left(\log E_{t}\right)+\frac{\sigma_{t}^{F}}{\sigma_{t}^{E}} \Delta\left(\log F_{t}\right)
$$

where $\sigma_{t}^{F} / \sigma_{t}^{E}$ is the ratio of the standard deviation of the two variables calculated recursively throughout the sample period. We then define a binary variable indicating stock market busts as

$$
B_{t}= \begin{cases}1 & \text { if } \Delta C_{t}<\mu_{t}^{\Delta C}-\delta \sigma_{t}^{\Delta C}, \\ 0 & \text { otherwise }\end{cases}
$$

where $\mu_{t}^{\Delta C}$ and $\sigma_{t}^{\Delta C}$ are the mean and standard deviation of $\Delta C_{t}$ computed recursively. The threshold parameter $\delta$ is chosen to be equal to the $90 \%$ Gaussian-quantile of the composite indicator $\Delta C_{t}$, i.e. $\delta=1.25 .{ }^{14}$ Due to the recursive calculations of $\sigma_{t}^{F}, \sigma_{t}^{E}, \mu_{t}^{\Delta C}$, and $\sigma_{t}^{\Delta C}$, few observations at the beginning of the sample are lost and in particular in what follows the binary indicator $B_{t}$ starts in 1985:Q2. Finally, we define a bust if for at least two consecutive quarters $B_{t}$ is equal to one. ${ }^{15}$ Using the described procedure, and consistently with Gerdesmeier et al. (2010), we find two busts in the sample considered: the first from 2002:Q3 to 2003:Q1, while the second, corresponding to the recent Great Financial Crisis, running from 2007:Q4 to the end of the sample in 2008:Q4.

We then consider three possible leading indicators of a stock market bust: $(i)$ the cointegration residual of money demand, i.e. the monetary overhang $\widehat{\eta}_{1, t}$ as given in (9), (ii) the spread between long-term interest rates and the own rate of money, $\left(\ell_{t}-o_{t}\right)$ (see, for example, Estrella and Mishkin, 1998), and (iii) the credit-to-GDP ratio, here proxied by loans-to-GDP ratio, $\left(l_{t}-y_{t}\right)$ (see, among others, Alessi and Detken, 2011; Angelini et al., 2011; Schularick and Taylor, 2012). We estimate probit regressions using different combinations of the three considered explanatory variables and in table 9 we report the results. We also provide two $R^{2}$ measures of goodness-of-fit as proposed in Estrella and Mishkin (1998). According to these measures, including the monetary overhang significantly increases the probability of correctly predicting stock market busts, even when controlling for spreads and credit-to-GDP ratio. Thus it can be considered as a leading indicator of periods of financial instability.

Finally, as a measure of particular interest for policy makers, we can consider the noise-tosignal ratio, i.e. the ratio between the percentage of bad signals over the percentage of good signals as predicted by the estimated probit model. At each point in time we can compare the predicted probabilities with the actual values of $B_{t}$. Four outcomes are possible: $(A)$ correctly predicted busts; $(B)$ false alarms; $(C)$ missed busts; $(D)$ correctly predicted quiet periods. The noise-to-signal ratio is then defined as:

$$
N t S=\frac{\frac{B}{B+D}}{\frac{A}{A+C}}
$$

This measure depends on how we define a signal. Indeed, a threshold level $\zeta$ is usually chosen, such that $\widehat{p}_{t}$ corresponds to a signal only if it is larger than $\zeta$. By increasing $\zeta, N t S$ can be

\footnotetext{
${ }^{13}$ The series of equity growth rate $\Delta\left(\log E_{t}\right)$ is the same as the one from which we build the variable $\Delta e_{t}$ and used by Carstensen (2006). The series of house prices growth rate $\Delta\left(\log F_{t}\right)$ is the same as the one from which we compute the real financial wealth series $f_{t}$ and used by Dreger and Wolters (2010b). See the appendix for details on these series.

${ }^{14}$ Results with different values of $\delta$ are qualititatively similar.

${ }^{15}$ Another way to build a similar indicator of financial markets activity but based on data in levels is proposed by Alessi and Detken (2011).
} 
made smaller. However, it has to be understood that minimizing $N t S$ is not necessarily the optimal choice. Instead it depends on the weights assigned to Type I errors (missed busts as percentage of periods in which a bust occurred), i.e. $C /(A+C)$ and to Type II errors (false alarms as percentage of periods in which no bust occurred), i.e. $B /(B+D)$. This is a policy problem studied in the literature, which has proposed different methods to choose $\zeta$ from the data (see e.g. Alessi and Detken, 2011). Although important, this is an issue beyond the scope of this paper and therefore, following the literature, we fix exogenously $\zeta=0.25$ or 0.35 (see Gerdesmeier et al., 2010, and references therein). With these choices we obtain for model VI in table 9 a noise-to-signal ratio of 0.04 and 0.02 respectively, which means that we have less than $4 \%$ or $2 \%$ chances of making errors when predicting stock market busts. In figure 5 we show the cointegration residual of our proposed money demand (the solid line) as leading indicator of stock market busts. Crosses represent the predicted signals from the probit model VI when using $\zeta=0.25$, while shaded areas are the busts defined according the binary indicator $B_{t}$. We fully capture the two periods of turmoil, the first from 2001 to 2003 and the second from 2007 to the end of 2008 corresponding to the Great Financial Crisis.

Price stability. Beyond the traditional link between money growth and inflation aimed at assessing risks for price stability due to excess liquidity (see e.g. McCallum and Nelson, 2010; De Santis et al., 2012), there is a growing interest in understanding the effects of unconventional monetary policies by the ECB and other central banks, i.e. liquidity injections, in terms of future inflation (see e.g. Dreger and Wolters, 2011). Moreover, Reynard (2012) investigates the empirical relation between money and inflation, focusing on the linkage between monetary developments during financial crises and the subsequent related inflation paths. For these reasons, in a second exercise, we evaluate the relevance of our monetary overhang measure in explaining inflation.

In order to do so, we estimate three different linear specifications. The first one is an autoregressive model of inflation itself, while in the second we add the monetary overhang computed from (9), and in the third we also control for the growth rate of GDP, in order to mimic a two pillars Phillips Curve (Gerlach, 2004). Table 10 displays the results of the regression analysis. Two findings are worth mentioning. First, the monetary overhang has the expected positive sign and it significantly leads with three lags inflation, also when controlling for an economic activity motive. Hence excess liquidity rises inflation. Second, the magnitude of the reaction is substantially lower from the one achieved by, among others, Gerlach and Svensson (2003). This seems to confirm the weakening of the quantitative relation between money and inflation in the EA, highlighted, for example, by Hofmann (2009). Moreover, the generalized impulse response of inflation to money disequilibrium, shown in figure 4.b, displays a permanent but small long-run impact of shocks to excess liquidity on inflation. In particular, for a $3 \%$ of actual money growth surplus with respect to its long-run value, a rise of almost $0.15 \%$ is observed. ${ }^{16}$

Prediction. Finally, we use the model estimated from 1980:Q1 to 2008:Q4 to run two exercises (see also De Santis et al., 2012; Giannone et al., 2012, for similar procedures). First, we compare the actual annual growth rates with those predicted by our model for the period 1980:Q1-2008:Q4. Results are shown in the top panel of figure 6 and confirm the ability of our model in describing the dynamics not only of real M3 but also of GDP growth rates. Second,

\footnotetext{
${ }^{16}$ The shock to money disequilibrium is approximately equal to $3 \%$.
} 
we compute one-step-ahead forecasts for the period 2009:Q1-2010:Q4. More precisely, at time $T+1$, we compute for model (8) the expectation conditional on information at time $T$ :

$$
\Delta \mathbf{Z}_{T+1 \mid T}=\widehat{\gamma}_{0}+\widehat{\boldsymbol{\alpha}} \widehat{\boldsymbol{\beta}}^{\prime} \mathbf{Z}_{T}+\sum_{j=1}^{p-1} \widehat{\Gamma}_{j} \Delta \mathbf{Z}_{T-j+1},
$$

the first and second row of $\Delta \mathbf{Z}_{T+1 \mid T}$ contain the predictions of real money balances and GDP growth rates. We repeat this procedure by forecasting at $T+2$ using data up to $T+1$, but without reestimating the coefficients, and we continue until we reach the last available quarter 2010:Q4. The result for the annualized forecasts is shown in the bottom panel of figure 6 together with $90 \%$ confidence intervals. Except for the first predicted quarter of GDP our model mimics fairly well the behaviour of the observed variables, even in a period of high turmoil as the recent years. ${ }^{17}$ As a final confirmation of the good performance of our model in describing real money balances and GDP dynamics, in table 11 we display root mean squared errors to compare our predictions with those obtained by estimating the models by De Santis et al. (2012) and De Bondt (2010).

\section{Concluding remarks}

In this paper we have reconsidered the role of money demand equations in the ECB monetary policy strategy. In order to do so, we need to deal with the issue of recent instability of estimated long-run equations for EA M3.

Hence, we firstly perform a model evaluation exercise, applying the new time-varying cointegration test by Bierens and Martins (2010) to compare some of the main specifications of EA money demand proposed by the literature and claiming to find a stable relation, once accounting for new motives for holding money (Carstensen, 2006; De Santis et al., 2012; Beyer, 2009; De Bondt, 2010; Dreger and Wolters, 2010a). The majority of considered models fail in delivering a time-invariant relation after 2001, except for the specification proposed by De Santis et al. (2012), including the spread between EA and US price-earnings ratios, as proxy of international financial markets, and the one by De Bondt (2010), using changes in EA unemployment rate, as proxy of a precautionary motive. However, neither of these models is stable when allowing for more than one long-run relation. Therefore, secondly, we propose, estimate and identify a new stable specification for money demand in which real balances depend on both the former variables. The model is economically meaningful and time-invariant for each time span and cointegration rank considered. Thus, both the speculative and the precautionary motive are relevant in order to understand the demand for EA M3.

In terms of policy, we provide a number of implications for the ECB. As for the increasing attention that monetary aggregates are gaining in strategies oriented to pursue financial stability (De Grauwe and Gros, 2009; Galí, 2010; Kim et al., 2012), our findings suggest that the estimated monetary overhang is a useful leading indicator of stock markets busts. It may thus help for the implementation of macroprudential policies, complementing other variables such as the yield curve and loans-to-GDP ratio, considered as the most relevant predictors of financial crises (Bank of International Settlements, 2010; Angelini et al., 2011).

\footnotetext{
${ }^{17}$ A possible explanation for this occurrence is that 2009:Q1 is the period immediately after Lehman Brothers failure, which was the most turbulent and rich of extraordinary measures, e.g. think of the abrupt trend inversion in ECB interest rates.
} 
Concerning price stability, our measure of excess liquidity is a valid explanatory variable for inflation, although with a modest impact. This seems to confirm that Quantitative Easing policies should not trigger an outburst in inflation, as pointed out by Lenza et al. (2010).

Finally, the results of a forecasting exercise suggest that information stemming from the proposed long-run structure may help in capturing the dynamic path of broad money and GDP growth during the Great Financial Crisis, a non-trivial task in such turbulent times.

As a by product of the specified stable CVAR model we also obtain a long-run aggregate demand equation and a relation between inflation and interest rates. A deeper study of these relations jointly with the money demand equation here proposed should allow for a broader focus and the set-up of a model linking monetary, financial and labour markets for the EA, with the aim of improving our understanding of the crisis. This is however far beyond the scope of this paper, and it is therefore left to future research.

\section{References}

Adrian, T., Shin, H. S., 2009. Money, liquidity, and monetary policy. American Economic Review 99 (2), 600-605.

Alessi, L., Detken, C., 2011. Quasi real time early warning indicators for costly asset price boom/bust cycles: A role for global liquidity. European Journal of Political Economy 27 (3), $520-533$.

Angelini, P., Neri, S., Panetta, F., Mar 2011. Monetary and macroprudential policies. Temi di discussione (economic working papers), Bank of Italy, Economic Research Department.

Artis, M., Beyer, A., 2004. Issues in money demand. the case of Europe. Journal of Common Market Studies 42, 717-736.

Ball, L., 2001. Another look at long-run money demand. Journal of Monetary Economics 47 (1), 31-44.

Bank of International Settlements, 2010. Guidances for national authorities operating the countercyclical capital buffer. Basel Committe on Banking Supervision Working Paper 187, Bank of International Settlements.

Beck, G. W., Wieland, V., 2008. Central bank misperceptions and the role of money in interest-rate rules. Journal of Monetary Economics 55 (Supplement), S1-S17.

Beyer, A., 2009. A stable model for Euro Area money demand: Revisiting the role of wealth. Working Paper 1111, European Central Bank.

Beyer, A., Farmer, R. E., 2007. Natural rate doubts. Journal of Economic Dynamics and Control 31 (3), 797-825.

Bierens, H., Martins, L., 2010. Time varying cointegration. Econometric Theory 26, 14531490.

Bordo, M. D., Haubrich, J. G., 2010. Credit crises, money and contractions: An historical view. Journal of Monetary Economics 57, 1-18. 
Borio, C., 2006. Monetary and financial stability: Here to stay? Journal of Banking \& Finance 30 (12), 3407-3414.

Brand, C., Cassola, N., 2004. A money demand system for euro area M3. Applied Economics $36,817-838$.

Bruggemann, A., Donati, P., Warne, A., 2003. Is the demand for Euro Area M3 stable? Working Paper 255, European Central Bank.

Buiter, W. H., 2012. The role of central banks in financial stability: How has it changed? Discussion Papers 8780, C.E.P.R.

Calza, A., Gerdesmeier, D., Levy, J., 2001. Euro area money demand: Measuring the opportunity cost appropriately. Working Paper 01/179, International Monetary Fund.

Carstensen, K., 2006. Stock market downswing and the stability of European Monetary Union money demand. Journal of Business and Economics Statistics 24, 395-402.

Coenen, G., Vega, J. L., 2001. The demand for M3 in the euro area. Journal of Applied Econometrics 16, 727-748.

De Bondt, G. J., 2010. New evidence on the motives for holding euro area money. The Manchester School 78, 259-278.

De Grauwe, P., Gros, D., 2009. A new two-pillar strategy for the ECB. Policy Brief 191, CEPS.

De Santis, R., Favero, C. A., Roffia, B., 2012. Euro area money demand and international portfolio allocation: A contribution to assessing risks to price stability. Journal of International Money and Finance available online.

Dreger, C., Wolters, J., 2010a. Investigating M3 money demand in the euro area. Journal of International Money and Finance 29, 111-122.

Dreger, C., Wolters, J., 2010b. Money demand and the role of monetary indicators in forecasting euro area inflation. Discussion Papers 1064, DIW Berlin, German Institute for Economic Research.

Dreger, C., Wolters, J., 2011. Money and inflation in the euro area during the financial crisis. Discussion Papers 1131, DIW Berlin, German Institute for Economic Research.

Estrella, A., 2005. Why does the yield curve predict output and inflation? Economic Journal $115,722-744$.

Estrella, A., Mishkin, F. S., 1998. Predicting U.S. recessions: Financial variables as leading indicators. The Review of Economics and Statistics 80, 45-61.

European Central Bank, 2003. Economic developments in the euro area. Monthly Bulletin May, ECB.

Fagan, G., Henry, J., Mestre, R., 2001. An Area-Wide Model for the euro area. Working Paper 42, ECB. 
Fanelli, L., Paruolo, P., 2010. Speed of adjustment in cointegrated systems. Journal of Econometrics 158 (1), 130-141.

Favara, G., Giordani, P., 2009. Reconsidering the role of money for output, prices and interest rates. Journal of Monetary Economics 56 (3), 419-430.

Fischer, B., Lenza, M., Pill, H., Reichlin, L., 2009. Monetary analysis and monetary policy in the euro area 1999-2006. Journal of International Money and Finance 28 (7), 1138-1164.

Funke, M., 2001. Money demand in euroland. Journal of International Money and Finance $20(5), 701-713$.

Galí, J., 2008. Monetary Policy, Inflation and the Business Cycle: An Introduction to the New Keynesian Framework. Princeton University Press, Princeton, New Jersey.

Galí, J., 2010. The monetary pillar and the Great Financial crisis, CREI, Universitat Pompeu Fabra, mimeo.

Gerdesmeier, D., Reimers, H.-E., Roffia, B., 2010. Asset price misalignments and the role of money and credit. International Finance 13 (3), 377-407.

Gerlach, S., 2004. The two pillars of the European Central Bank. Economic Policy 19 (40), 389-439.

Gerlach, S., Svensson, L. E. O., 2003. Money and inflation in the euro area: A case for monetary indicators? Journal of Monetary Economics 50 (8), 1649-1672.

Giannone, D., Lenza, M., Reichlin, L., 2012. Money, credit, monetary policy and the business cycle in the euro area. Working Paper 2012-008, ECARES.

Golinelli, R., Pastorello, S., 2002. Modeling the demand for M3 in the euro area. European Journal of Finance 8, 371-401.

Hafer, R., Haslag, J. H., Jones, G., April 2007. On money and output: Is money redundant? Journal of Monetary Economics 54 (3), 945-954.

Hofmann, B., 2009. Do monetary aggregates lead euro area inflation? Journal of International Money and Finance 28 (7), 1165-1181.

Johansen, S., 1996. Likelihood-based inference in Cointegrated Vector Autoregressive Models. Oxford University Press, Oxford.

Juselius, K., 2006. The Cointegrated VAR Model: Methodology and Applications. Oxford University Press.

Kim, H. J., Shin, H. S., Yun, J., 2012. Monetary aggregates and the Central Bank Financial Stability Mandate, Bank of Korea, Princeton University and Ewha Womans.

King, R. G., Plosser, C. I., Stock, J. H., Watson, M. W., 1991. Stochastic trends and economic fluctuations. American Economic Review 81 (4), 819-40.

Koop, G., Leon-Gonzalez, R., Strachan, R. W., 2011. Bayesian inference in a time varying cointegration model. Journal of Econometrics 165 (2), 210-220. 
Lenza, M., Pill, H., Reichlin, L., 2010. Monetary policy in exceptional times. Economic Policy 25 (62), 295-339.

McCallum, B. T., Nelson, E., 2010. Money and inflation: Some critical issues. In: Friedman, B. M., Woodford, M. (Eds.), Handbook of Monetary Economics. Vol. 3 of Handbook of Monetary Economics. Elsevier, Ch. 3, pp. 97-153.

Mizon, G. E., Richard, J., 1986. The Encompassing Principle and its application to testing non-nested hypotheses. Econometrica 54, 657-678.

Nelson, E., 2002. Direct effects of base money on aggregate demand: Theory and evidence. Journal of Monetary Economics 49 (4), 687-708.

Nelson, E., 2003. The future of monetary aggregates in monetary policy analysis. Journal of Monetary Economics 50 (5), 1029-1059.

Nelson, E., 2008. Why money growth determines inflation in the long run: Answering the woodford critique. Journal of Money, Credit and Banking 40 (8), 1791-1814.

Papademos, L. D., Stark, J. (Eds.), 2010. Enhancing Monetary Analysis. European Central Bank.

Park, J. Y., Hahn, S. B., 1999. Cointegrating regressions with time varying coefficients. Econometric Theory 15, 664-703.

Pesaran, H. H., Shin, Y., 1998. Generalized impulse response analysis in linear multivariate models. Economics Letters 58 (1), 17-29.

Reynard, S., 2007. Maintaining low inflation: Money, interest rates, and policy stance. Journal of Monetary Economics 54 (5), 1441-1471.

Reynard, S., 2012. Financial crises, money and inflation, Swiss National Bank, mimeo.

Rudebusch, G. D., Svensson, L. E. O., 2002. Eurosystem monetary targeting: Lessons from U.S. data. European Economic Review 46 (3), 417-442.

Sargent, T. J., Surico, P., 2011. Two illustrations of the quantity theory of money: Breakdowns and revivals. American Economic Review 101 (1), 109-28.

Schularick, M., Taylor, A. M., 2012. Credit booms gone bust: Monetary policy, leverage cycles, and financial crises, 1870Đ2008. American Economic Reivew 102 (3), 1029-1061.

Setzer, R., den Noord, P. V., Wolff, G., 2011. Heterogeneity in money holdings across euro area countries: The role of housing. European Journal of Political Economy 27 (3), 764-780.

Smets, F., Wouters, R., 2003. An estimated dynamic stochastic general equilibrium model of the euro area. Journal of the European Economic Association 1 (5), 1123-1175.

Stock, J. H., Watson, M. W., 1993. A simple estimator of cointegrating vectors in higher order integrated systems. Econometrica 61 (4), 783-820.

Teles, P., Uhlig, H., 2010. Is quantity theory still alive? NBER Working Papers 16393, National Bureau of Economic Research, Inc. 
Vlaar, P. J. G., 2004. Shocking the eurozone. European Economic Review 48 (1), 109-131.

Weber, A. A., Gerke, R., Worms, A., 2011. Changes in euro area monetary transmission? Applied Financial Economics 21, 131-145.

Woodford, M., 2003. Interest and prices: Foundations of a Theory of Monetary Policy. Princeton University Press.

Woodford, M., 2007. Does a two pillars Phillips curve justify a two pillars monetary policy strategy? Discussion Paper 6447, CEPR.

Woodford, M., 2008. How important is money in the conduct of monetary policy? Journal of Money, Credit and Banking 40 (8), 1561-1598. 


\section{Tables and figures}

Table 1: Euro Area money Demand in The literature.

\begin{tabular}{|c|c|c|c|}
\hline Ref. & $\mathbf{X}_{t}$ & $r$ & Sample \\
\hline Coenen and Vega (2001) & $\ell_{t}, s_{t}, \pi_{t}$ & 3 & 1980:Q1-1998:Q4 \\
\hline Calza et al. (2001) & $\left(s_{t}-o_{t}\right),\left(\ell_{t}-o_{t}\right)$ & 1 & 1980:Q1-1999:Q4 \\
\hline Calza et al. (2001) & $\left(s_{t}-o_{t}\right)$ & 1 & 1980:Q1-1999:Q4 \\
\hline Gerlach and Svensson (2003) & $\left(\ell_{t}-s_{t}\right)$ & 2 & 1980:Q1-2001:Q4 \\
\hline Vlaar (2004) & $\left(\ell_{t}-s_{t}\right), \pi_{t}$ & 3 & 1980:Q1-2000:Q4 \\
\hline Carstensen (2006) & $\left(s_{t}-o_{t}\right),\left(\Delta e_{t}-o_{t}\right), v_{t}$ & 1 & 1980:Q1-2003:Q4 \\
\hline Beyer (2009) & $o_{t}, s_{t}, \pi_{t}, \Delta h_{t}$ & 2 & 1980:Q1-2008:Q4 \\
\hline Beyer (2009) & $\Delta h_{t}$ & 2 & 1980:Q1-2008:Q4 \\
\hline Beyer (2009) & $\Delta h_{t}, \pi_{t}$ & 2 & 1980:Q1-2008:Q4 \\
\hline Dreger and Wolters (2010a) & $\pi_{t}$ & 1 & 1983:Q1-2004:Q4 \\
\hline Dreger and Wolters (2010b) & $s_{t}, l_{t}, \pi_{t}, f_{t}$ & 2 & 1983:Q1-2010:Q2 \\
\hline Dreger and Wolters (2010b) & $f_{t}, \pi_{t}$ & 1 & 1983:Q1-2010:Q2 \\
\hline Dreger and Wolters (2010b) & $f_{t}, \pi_{t},\left(l_{t}-s_{t}\right)$ & 2 & 1983:Q1-2010:Q2 \\
\hline De Bondt (2010) & $w_{t}, o t, \Delta e_{t}, \Delta u_{t}$ & 1 & 1983:Q1-2007:Q2 \\
\hline De Bondt (2010) & $w_{t}, o t, \Delta e_{t}$ & 1 & 1983:Q1-2007:Q2 \\
\hline De Bondt (2010) & $o_{t}, \Delta u_{t}$ & 2 & 1983:Q1-2007:Q2 \\
\hline De Santis et al. (2012) & $\ell_{t}, \ell_{t}^{*}, q_{t}, q_{t}^{*}, o_{t}$ & 3 & 1980:Q1-2007:Q3 \\
\hline De Santis et al. (2012) & $\ell_{t}, \ell_{t}^{*}, q_{t}, q_{t}^{*}$ & 3 & 1980:Q1-2007:Q3 \\
\hline De Santis et al. (2012) & $\left(\ell_{t}-\ell_{t}^{*}\right),\left(q_{t}-q_{t}^{*}\right)$ & 3 & 1980:Q1-2007:Q3 \\
\hline
\end{tabular}

The time-varying long run money demand equation considered is $\left(m_{t}-p_{t}\right)=\beta_{0}+\beta_{t}^{y} y_{t}+$ $\boldsymbol{\beta}_{t}^{X} \mathbf{X}_{t}$, where: $\left(m_{t}-p_{t}\right)=$ log-real balances, $y_{t}=$ log-real income, $\ell_{t}=$ long-term interest rate, $s_{t}=$ short-term interest rate, $o_{t}=$ own rate, $\pi_{t}=\mathrm{q}-\mathrm{o}-\mathrm{q}$ inflation rate (in Beyer (2009) y-o-y inflation rate), $\Delta e_{t}=$ q-o-q equity returns, $v_{t}=$ log-volatility of equity returns, $\Delta h_{t}=$ y-o-y housing wealth growth rate, $f_{t}=$ log-real financial wealth, $w_{t}=$ log-real wealth, $\Delta u_{t}$ $=\mathrm{y}-\mathrm{o}-\mathrm{y}$ differences of unemployment rate, $\ell_{t}^{*}=\mathrm{US}$ long-term interest rate, $q_{t}=\log$-price to earnings ratio, $q_{t}^{*}=\mathrm{US}$ log-price to earnings ratio. 
Table 2: Likelihood-ratio test, $L R_{T}$. Classical specifications $(p=2)$.

\begin{tabular}{|c|c|c|c|c|c|c|c|c|c|c|c|c|c|}
\hline \multirow[b]{2}{*}{ Ref. } & \multirow[b]{2}{*}{$\mathbf{X}_{t}$} & \multicolumn{3}{|c|}{ 1980:Q1-2001:Q4 } & \multicolumn{3}{|c|}{ 1980:Q1-2007:Q4 } & \multicolumn{3}{|c|}{ 1980:Q1-2008:Q4 } & \multicolumn{3}{|c|}{ 1980:Q1-2009:Q4 } \\
\hline & & $r=1$ & $r=2$ & $r=3$ & $r=1$ & $r=2$ & $r=3$ & $r=1$ & $r=2$ & $r=3$ & $r=1$ & $r=2$ & $r=3$ \\
\hline $\mathrm{CV}$ & $\ell_{t}, s_{t}, \pi_{t}$ & $\begin{array}{c}21.14 \\
(0.00)\end{array}$ & $\begin{array}{l}44.85 \\
(0.00)\end{array}$ & $\begin{array}{c}63.71 \\
(0.00)\end{array}$ & $\begin{array}{c}24.61 \\
(0.00)\end{array}$ & $\begin{array}{l}47.61 \\
(0.00)\end{array}$ & $\begin{array}{l}73.37 \\
(0.00)\end{array}$ & $\begin{array}{c}26.59 \\
(0.00)\end{array}$ & $\begin{array}{l}51.72 \\
(0.00)\end{array}$ & $\begin{array}{l}65.90 \\
(0.00)\end{array}$ & $\begin{array}{c}25.77 \\
(0.00)\end{array}$ & $\begin{array}{l}50.25 \\
(0.00)\end{array}$ & $\begin{array}{c}63.12 \\
(0.00)\end{array}$ \\
\hline CGL & $\left(s_{t}-o_{t}\right),\left(\ell_{t}-o_{t}\right)$ & $\begin{array}{l}16.50 \\
(0.00)\end{array}$ & $\begin{array}{l}36.84 \\
(0.00)\end{array}$ & $\begin{array}{l}45.58 \\
(0.00)\end{array}$ & $\begin{array}{l}21.65 \\
(0.00)\end{array}$ & $\begin{array}{l}39.67 \\
(0.00)\end{array}$ & $\begin{array}{l}56.13 \\
(0.00)\end{array}$ & $\begin{array}{c}24.57 \\
(0.00)\end{array}$ & $\begin{array}{l}38.98 \\
(0.00)\end{array}$ & $\begin{array}{l}55.03 \\
(0.00)\end{array}$ & $\begin{array}{c}27.14 \\
(0.00)\end{array}$ & $\begin{array}{l}38.30 \\
(0.00)\end{array}$ & $\begin{array}{l}48.07 \\
(0.00)\end{array}$ \\
\hline CGL & $\left(s_{t}-o_{t}\right)$ & $\begin{array}{l}18.50 \\
(0.00)\end{array}$ & $\begin{array}{l}33.06 \\
(0.00)\end{array}$ & $\begin{array}{l}36.06 \\
(0.00)\end{array}$ & $\begin{array}{l}18.08 \\
(0.00)\end{array}$ & $\begin{array}{l}37.45 \\
(0.00)\end{array}$ & $\begin{array}{l}39.24 \\
(0.00)\end{array}$ & $\begin{array}{c}20.51 \\
(0.00)\end{array}$ & $\begin{array}{l}36.21 \\
(0.00)\end{array}$ & $\begin{array}{l}38.05 \\
(0.00)\end{array}$ & $\begin{array}{c}26.92 \\
(0.00)\end{array}$ & $\begin{array}{l}36.91 \\
(0.00)\end{array}$ & $\begin{array}{l}39.55 \\
(0.00)\end{array}$ \\
\hline GS & $\left(\ell_{t}-s_{t}\right)$ & $\begin{array}{r}2.18 \\
(0.54)\end{array}$ & $\begin{array}{l}14.42 \\
(0.03)\end{array}$ & $\begin{array}{l}17.02 \\
(0.05)\end{array}$ & $\begin{array}{l}17.43 \\
(0.00)\end{array}$ & $\begin{array}{l}34.77 \\
(0.00)\end{array}$ & $\begin{array}{l}35.34 \\
(0.00)\end{array}$ & $\begin{array}{l}14.56 \\
(0.00)\end{array}$ & $\begin{array}{l}30.07 \\
(0.00)\end{array}$ & $\begin{array}{l}32.03 \\
(0.00)\end{array}$ & $\begin{array}{l}16.89 \\
(0.00)\end{array}$ & $\begin{array}{l}26.63 \\
(0.00)\end{array}$ & $\begin{array}{r}29.30 \\
(0.00)\end{array}$ \\
\hline V & $\left(\ell_{t}-s_{t}\right), \pi_{t}$ & $\begin{array}{l}10.92 \\
(0.03)\end{array}$ & $\begin{array}{c}29.28 \\
(0.00)\end{array}$ & $\begin{array}{l}42.62 \\
(0.00)\end{array}$ & $\begin{array}{l}15.79 \\
(0.00)\end{array}$ & $\begin{array}{l}32.81 \\
(0.00)\end{array}$ & $\begin{array}{l}52.50 \\
(0.00)\end{array}$ & $\begin{array}{l}16.08 \\
(0.00)\end{array}$ & $\begin{array}{l}30.70 \\
(0.00)\end{array}$ & $\begin{array}{l}41.71 \\
(0.00)\end{array}$ & $\begin{array}{l}19.49 \\
(0.00)\end{array}$ & $\begin{array}{l}33.27 \\
(0.00)\end{array}$ & $\begin{array}{l}41.32 \\
(0.00)\end{array}$ \\
\hline
\end{tabular}

Values for the Bierens and Martins (2010) likelihood ratio test $L R_{T}$ which under the null hypothesis of time-invariant cointegration is distributed as $\chi_{(r m k)}^{2}$, with $m=1$ and $k$ equal to the size of $\mathbf{X}_{t}$ plus 2. Corresponding $p$-values in parenthesis. The time-varying long run money demand equation considered is $\left(m_{t}-p_{t}\right)=\beta_{0}+\beta_{t}^{y} y_{t}+\boldsymbol{\beta}_{t}^{X} \mathbf{X}_{t}$, where: $\left(m_{t}-p_{t}\right)=$ log-real balances, $y_{t}=\log$-real income, $s_{t}=$ short-term interest rate, $\ell_{t}=$ long-term interest rate, $o_{t}=$ own rate, $\pi_{t}=$ q-o-q inflation rate.

CV: Coenen and Vega (2001); CGL: Calza et al. (2001); GS: Gerlach and Svensson (2003); V: Vlaar (2004). 
Table 3: Likelihood-Ratio test $L R_{T}$. Financial And housing markets specifications $(p=2)$.

\begin{tabular}{|c|c|c|c|c|c|c|c|c|c|c|c|c|c|}
\hline \multirow[b]{2}{*}{ Ref. } & \multirow[b]{2}{*}{$\mathbf{X}_{t}$} & \multicolumn{3}{|c|}{ 1980:Q1-2001:Q4 } & \multicolumn{3}{|c|}{ 1980:Q1-2007:Q4 } & \multicolumn{3}{|c|}{ 1980:Q1-2008:Q4 } & \multicolumn{3}{|c|}{ 1980:Q1-2009:Q4 } \\
\hline & & $r=1$ & $r=2$ & $r=3$ & $r=1$ & $r=2$ & $r=3$ & $r=1$ & $r=2$ & $r=3$ & $r=1$ & $r=2$ & $r=3$ \\
\hline $\mathrm{C}$ & $\left(s_{t}-o_{t}\right),\left(\Delta e_{t}-o_{t}\right), v_{t}$ & $\begin{array}{l}16.46 \\
(0.01)\end{array}$ & $\begin{array}{l}40.43 \\
(0.00)\end{array}$ & $\begin{array}{c}58.02 \\
(0.00)\end{array}$ & $\begin{array}{c}37.46 \\
(0.00)\end{array}$ & $\begin{array}{l}61.40 \\
(0.00)\end{array}$ & $\begin{array}{c}76.05 \\
(0.00)\end{array}$ & $\begin{array}{c}26.13 \\
(0.00)\end{array}$ & $\begin{array}{l}49.05 \\
(0.00)\end{array}$ & $\begin{array}{c}64.22 \\
(0.00)\end{array}$ & $\begin{array}{l}31.39 \\
(0.00)\end{array}$ & $\begin{array}{l}47.24 \\
(0.00)\end{array}$ & $\begin{array}{l}63.03 \\
(0.00)\end{array}$ \\
\hline B & $o_{t}, s_{t}, \pi_{t}, \Delta h_{t}$ & $\begin{array}{c}33.42 \\
(0.00)\end{array}$ & $\begin{array}{l}57.05 \\
(0.00)\end{array}$ & $\begin{array}{l}75.16 \\
(0.00)\end{array}$ & $\begin{array}{c}28.52 \\
(0.00)\end{array}$ & $\begin{array}{l}45.53 \\
(0.00)\end{array}$ & $\begin{array}{l}61.82 \\
(0.00)\end{array}$ & $\begin{array}{c}25.26 \\
(0.00)\end{array}$ & $\begin{array}{l}49.77 \\
(0.00)\end{array}$ & $\begin{array}{l}64.51 \\
(0.00)\end{array}$ & $\begin{array}{c}26.86 \\
(0.00)\end{array}$ & $\begin{array}{c}52.39 \\
(0.00)\end{array}$ & $\begin{array}{c}66.82 \\
(0.00)\end{array}$ \\
\hline B & $\Delta h_{t}$ & $\begin{array}{r}1.25 \\
(0.74)\end{array}$ & $\begin{array}{r}7.35 \\
(0.29)\end{array}$ & $\begin{array}{l}10.74 \\
(0.29)\end{array}$ & $\begin{array}{c}20.14 \\
(0.00)\end{array}$ & $\begin{array}{c}27.09 \\
(0.00)\end{array}$ & $\begin{array}{c}27.38 \\
(0.00)\end{array}$ & $\begin{array}{c}21.47 \\
(0.00)\end{array}$ & $\begin{array}{r}27.90 \\
(0.00)\end{array}$ & $\begin{array}{c}31.13 \\
(0.00)\end{array}$ & $\begin{array}{c}24.33 \\
(0.00)\end{array}$ & $\begin{array}{c}27.83 \\
(0.00)\end{array}$ & $\begin{array}{c}29.98 \\
(0.00)\end{array}$ \\
\hline B & $\Delta h_{t}, \pi_{t}$ & $\begin{array}{c}28.65 \\
(0.00)\end{array}$ & $\begin{array}{c}29.74 \\
(0.00)\end{array}$ & $\begin{array}{c}33.72 \\
(0.00)\end{array}$ & $\begin{array}{l}15.49 \\
(0.00)\end{array}$ & $\begin{array}{l}32.50 \\
(0.00)\end{array}$ & $\begin{array}{l}49.64 \\
(0.00)\end{array}$ & $\begin{array}{c}20.57 \\
(0.01)\end{array}$ & $\begin{array}{c}33.49 \\
(0.00)\end{array}$ & $\begin{array}{l}49.27 \\
(0.00)\end{array}$ & $\begin{array}{l}19.83 \\
(0.00)\end{array}$ & $\begin{array}{c}29.36 \\
(0.00)\end{array}$ & $\begin{array}{l}39.19 \\
(0.00)\end{array}$ \\
\hline DW & $s_{t}, l_{t}, \pi_{t}, f_{t}$ & $\begin{array}{l}33.27 \\
(0.00)\end{array}$ & $\begin{array}{l}53.60 \\
(0.00)\end{array}$ & $\begin{array}{l}77.86 \\
(0.00)\end{array}$ & $\begin{array}{c}33.86 \\
(0.00)\end{array}$ & $\begin{array}{l}64.72 \\
(0.00)\end{array}$ & $\begin{array}{l}89.02 \\
(0.00)\end{array}$ & $\begin{array}{l}30.43 \\
(0.00)\end{array}$ & $\begin{array}{c}65.45 \\
(0.00)\end{array}$ & $\begin{array}{c}88.68 \\
(0.00)\end{array}$ & $\begin{array}{l}42.26 \\
(0.00)\end{array}$ & $\begin{array}{c}82.15 \\
(0.00)\end{array}$ & $\begin{array}{r}109.27 \\
(0.00)\end{array}$ \\
\hline DW & $\pi_{t}$ & $\begin{array}{l}12.76 \\
(0.01)\end{array}$ & $\begin{array}{c}27.34 \\
(0.00)\end{array}$ & $\begin{array}{l}34.96 \\
(0.00)\end{array}$ & $\begin{array}{l}16.32 \\
(0.00)\end{array}$ & $\begin{array}{l}38.71 \\
(0.00)\end{array}$ & $\begin{array}{l}42.85 \\
(0.00)\end{array}$ & $\begin{array}{l}20.31 \\
(0.00)\end{array}$ & $\begin{array}{l}33.33 \\
(0.00)\end{array}$ & $\begin{array}{l}38.94 \\
(0.00)\end{array}$ & $\begin{array}{l}23.17 \\
(0.00)\end{array}$ & $\begin{array}{l}31.77 \\
(0.00)\end{array}$ & $\begin{array}{l}36.23 \\
(0.00)\end{array}$ \\
\hline DW & $f_{t}, \pi_{t}$ & $\begin{array}{l}10.85 \\
(0.03)\end{array}$ & $\begin{array}{c}23.36 \\
(0.00)\end{array}$ & $\begin{array}{l}40.93 \\
(0.00)\end{array}$ & $\begin{array}{c}23.05 \\
(0.00)\end{array}$ & $\begin{array}{l}42.34 \\
(0.00)\end{array}$ & $\begin{array}{c}50.59 \\
(0.00)\end{array}$ & $\begin{array}{c}25.15 \\
(0.00)\end{array}$ & $\begin{array}{l}44.60 \\
(0.00)\end{array}$ & $\begin{array}{c}58.99 \\
(0.00)\end{array}$ & $\begin{array}{c}26.59 \\
(0.00)\end{array}$ & $\begin{array}{c}55.14 \\
(0.00)\end{array}$ & $\begin{array}{l}65.34 \\
(0.00)\end{array}$ \\
\hline DW & $f_{t}, \pi_{t},\left(l_{t}-s_{t}\right)$ & $\begin{array}{c}9.48 \\
(0.09)\end{array}$ & $\begin{array}{l}19.70 \\
(0.03)\end{array}$ & $\begin{array}{l}35.21 \\
(0.00)\end{array}$ & $\begin{array}{l}19.17 \\
(0.00)\end{array}$ & $\begin{array}{l}42.63 \\
(0.00)\end{array}$ & $\begin{array}{l}61.75 \\
(0.00)\end{array}$ & $\begin{array}{c}16.64 \\
(0.01)\end{array}$ & $\begin{array}{l}43.37 \\
(0.00)\end{array}$ & $\begin{array}{c}58.98 \\
(0.00)\end{array}$ & $\begin{array}{l}19.07 \\
(0.00)\end{array}$ & $\begin{array}{c}50.08 \\
(0.00)\end{array}$ & $\begin{array}{l}67.68 \\
(0.00)\end{array}$ \\
\hline
\end{tabular}

Values for the Bierens and Martins (2010) likelihood ratio test $L R_{T}$ which under the null hypothesis of time-invariant cointegration is distributed as $\chi_{(r m k)}^{2}$, with $m=1$ and $k$ equal to the size of $\mathbf{X}_{t}$ plus 2. Corresponding $p$-values in parenthesis. The time-varying long run money demand equation considered is $\left(m_{t}-p_{t}\right)=\beta_{0}+\beta_{t}^{y} y_{t}+\boldsymbol{\beta}_{t}^{X} \mathbf{X}_{t}$, where: $\left(m_{t}-p_{t}\right)=$ log-real balances, $y_{t}=$ log-real income, $s_{t}=$ short-term interest rate, $\ell_{t}=$ long-term interest rate, $o_{t}=$ own rate, $\pi_{t}=$ q-o-q inflation rate (in Beyer (2009) y-o-y inflation rate), $\Delta e_{t}$ $=$ q-o-q equity returns, $v_{t}=\log$-volatility of equity returns, $\Delta h_{t}=\mathrm{y}$-o-y housing wealth growth rate, $f_{t}=\log$-real financial wealth.

C: Carstensen (2006); B: Beyer (2009); DW: Dreger and Wolters (2010a,b). 
Table 4: Likelihood-RATio test $L R_{T}$. LABor And international FinANCIAL MARKets SPECifications $(p=2)$.

\begin{tabular}{|c|c|c|c|c|c|c|c|c|c|c|c|c|c|}
\hline \multirow[b]{2}{*}{ Ref. } & \multirow[b]{2}{*}{$\mathbf{X}_{t}$} & \multicolumn{3}{|c|}{ 1980:Q1-2001:Q4 } & \multicolumn{3}{|c|}{ 1980:Q1-2007:Q4 } & \multicolumn{3}{|c|}{ 1980:Q1-2008:Q4 } & \multicolumn{3}{|c|}{ 1980:Q1-2009:Q4 } \\
\hline & & $r=1$ & $r=2$ & $r=3$ & $r=1$ & $r=2$ & $r=3$ & $r=1$ & $r=2$ & $r=3$ & $r=1$ & $r=2$ & $r=3$ \\
\hline $\mathrm{D}$ & $w_{t}, o_{t}, \Delta e_{t}, \Delta u_{t}$ & $\begin{array}{l}19.57 \\
(0.00)\end{array}$ & $\begin{array}{l}39.63 \\
(0.00)\end{array}$ & $\begin{array}{l}77.24 \\
(0.00)\end{array}$ & $\begin{array}{l}10.38 \\
(0.11)\end{array}$ & $\begin{array}{l}34.83 \\
(0.00)\end{array}$ & $\begin{array}{l}58.66 \\
(0.00)\end{array}$ & $\begin{array}{c}21.00 \\
(0.00)\end{array}$ & $\begin{array}{l}39.25 \\
(0.00)\end{array}$ & $\begin{array}{l}67.29 \\
(0.00)\end{array}$ & $\begin{array}{l}27.00 \\
(0.00)\end{array}$ & $\begin{array}{l}52.99 \\
(0.00)\end{array}$ & $\begin{array}{l}79.24 \\
(0.00)\end{array}$ \\
\hline $\mathrm{D}$ & $w_{t}, o_{t}, \Delta e_{t}$ & $\begin{array}{l}12.01 \\
(0.03)\end{array}$ & $\begin{array}{l}39.76 \\
(0.00)\end{array}$ & $\begin{array}{l}55.25 \\
(0.00)\end{array}$ & $\begin{array}{l}14.67 \\
(0.01)\end{array}$ & $\begin{array}{l}44.05 \\
(0.00)\end{array}$ & $\begin{array}{l}79.43 \\
(0.00)\end{array}$ & $\begin{array}{l}17.22 \\
(0.00)\end{array}$ & $\begin{array}{l}43.30 \\
(0.00)\end{array}$ & $\begin{array}{l}73.22 \\
(0.00)\end{array}$ & $\begin{array}{l}31.60 \\
(0.00)\end{array}$ & $\begin{array}{l}58.97 \\
(0.00)\end{array}$ & $\begin{array}{l}83.73 \\
(0.00)\end{array}$ \\
\hline $\mathrm{D}$ & $o_{t}, \Delta u_{t}$ & $\begin{array}{r}0.96 \\
(0.92)\end{array}$ & $\begin{array}{l}23.75 \\
(0.00)\end{array}$ & $\begin{array}{l}36.46 \\
(0.00)\end{array}$ & $\begin{array}{r}9.11 \\
(0.06)\end{array}$ & $\begin{array}{l}53.43 \\
(0.00)\end{array}$ & $\begin{array}{l}70.60 \\
(0.00)\end{array}$ & $\begin{array}{l}13.45 \\
(0.01)\end{array}$ & $\begin{array}{l}53.58 \\
(0.00)\end{array}$ & $\begin{array}{l}68.90 \\
(0.00)\end{array}$ & $\begin{array}{r}6.46 \\
(0.17)\end{array}$ & $\begin{array}{l}48.88 \\
(0.00)\end{array}$ & $\begin{array}{l}63.87 \\
(0.00)\end{array}$ \\
\hline DFR & $\ell_{t}, \ell_{t}^{*}, q_{t}, q_{t}^{*}, o_{t}$ & $\begin{array}{l}36.24 \\
(0.00)\end{array}$ & $\begin{array}{l}67.10 \\
(0.00)\end{array}$ & $\begin{array}{r}101.43 \\
(0.00)\end{array}$ & $\begin{array}{l}23.56 \\
(0.00)\end{array}$ & $\begin{array}{l}58.79 \\
(0.00)\end{array}$ & $\begin{array}{l}85.16 \\
(0.00)\end{array}$ & $\begin{array}{l}16.15 \\
(0.02)\end{array}$ & $\begin{array}{l}45.88 \\
(0.00)\end{array}$ & $\begin{array}{l}79.75 \\
(0.00)\end{array}$ & $\begin{array}{l}24.30 \\
(0.00)\end{array}$ & $\begin{array}{l}57.06 \\
(0.00)\end{array}$ & $\begin{array}{c}78.63 \\
(0.00)\end{array}$ \\
\hline DFR & $\ell_{t}, \ell_{t}^{*}, q_{t}, q_{t}^{*}$ & $\begin{array}{l}14.60 \\
(0.02)\end{array}$ & $\begin{array}{l}27.18 \\
(0.01)\end{array}$ & $\begin{array}{l}47.11 \\
(0.00)\end{array}$ & $\begin{array}{r}4.57 \\
(0.60)\end{array}$ & $\begin{array}{l}26.32 \\
(0.01)\end{array}$ & $\begin{array}{l}42.59 \\
(0.00)\end{array}$ & $\begin{array}{c}8.32 \\
(0.22)\end{array}$ & $\begin{array}{c}34.92 \\
(0.00)\end{array}$ & $\begin{array}{l}54.41 \\
(0.00)\end{array}$ & $\begin{array}{r}4.20 \\
(0.65)\end{array}$ & $\begin{array}{l}28.82 \\
(0.00)\end{array}$ & $\begin{array}{l}46.48 \\
(0.00)\end{array}$ \\
\hline DFR & $\left(\ell_{t}-\ell_{t}^{*}\right),\left(q_{t}-q_{t}^{*}\right)$ & $\begin{array}{l}15.09 \\
(0.00)\end{array}$ & $\begin{array}{l}22.67 \\
(0.00)\end{array}$ & $\begin{array}{c}34.65 \\
(0.00)\end{array}$ & $\begin{array}{r}9.22 \\
(0.06)\end{array}$ & $\begin{array}{l}37.02 \\
(0.00)\end{array}$ & $\begin{array}{l}52.47 \\
(0.00)\end{array}$ & $\begin{array}{l}11.70 \\
(0.02)\end{array}$ & $\begin{array}{l}38.37 \\
(0.00)\end{array}$ & $\begin{array}{c}53.88 \\
(0.00)\end{array}$ & $\begin{array}{r}4.48 \\
(0.35)\end{array}$ & $\begin{array}{l}28.21 \\
(0.00)\end{array}$ & $\begin{array}{l}47.34 \\
(0.00)\end{array}$ \\
\hline
\end{tabular}

Values for the Bierens and Martins (2010) likelihood ratio test $L R_{T}$ which under the null hypothesis of time-invariant cointegration is distributed as $\chi_{(r m k)}^{2}$, with $m=1$ and $k$ equal to the size of $\mathbf{X}_{t}$ plus 2. Corresponding $p$-values in parenthesis. The time-varying long run money demand equation considered is $\left(m_{t}-p_{t}\right)=\beta_{0}+\beta_{t}^{y} y_{t}+\boldsymbol{\beta}_{t}^{X} \mathbf{X}_{t}$, where: $\left(m_{t}-p_{t}\right)=$ log-real balances, $y_{t}=\log$-real income, $\ell_{t}=$ long-term interest rate, $o_{t}=$ own rate, $\Delta e_{t}=$ q-o-q equity returns, $w_{t}=\log$-real wealth, $\Delta u_{t}=$ y-o-y differences of unemployment rate, $\ell_{t}^{*}=$ US long-term interest rate, $q_{t}=\log$-price to earnings ratio, $q_{t}^{*}=$ US log-price to earnings ratio.

D: De Bondt (2010); DFR: De Santis et al. (2012). 
Table 5: Likelihood-Ratio test $L R_{T}$. Barigozzi and Conti $\operatorname{specification~}(p=2)$.

\begin{tabular}{|c|c|c|c|c|c|c|c|c|c|}
\hline \multirow[b]{2}{*}{$\mathbf{X}_{t}$} & \multicolumn{3}{|c|}{ 1980:Q1-2007:Q4 } & \multicolumn{3}{|c|}{ 1980:Q1-2008:Q4 } & \multicolumn{3}{|c|}{ 1980:Q1-2009:Q4 } \\
\hline & $r=1$ & $r=2$ & $r=3$ & $r=1$ & $r=2$ & $r=3$ & $r=1$ & $r=2$ & $r=3$ \\
\hline$\Delta u_{t},\left(q_{t}-q_{t}^{*}\right),\left(\ell_{t}-o_{t}\right), \pi_{t}$ & $\begin{array}{l}10.30 \\
(0.11)\end{array}$ & $\begin{array}{l}16.29 \\
(0.18)\end{array}$ & $\begin{array}{l}34.68 \\
(0.01)\end{array}$ & $\begin{array}{l}12.28 \\
(0.11)\end{array}$ & $\begin{array}{l}16.34 \\
(0.41)\end{array}$ & $\begin{array}{l}36.68 \\
(0.11)\end{array}$ & $\begin{array}{l}10.23 \\
(0.05)\end{array}$ & $\begin{array}{l}15.08 \\
(0.11)\end{array}$ & $\begin{array}{l}29.61 \\
(0.02)\end{array}$ \\
\hline
\end{tabular}

Values for the Bierens and Martins (2010) likelihood ratio test $L R_{T}$ which under the null hypothesis of time-invariant cointegration is distributed as $\chi_{(r m k)}^{2}$, with $m=1$ and $k$ equal to the size of $\mathbf{X}_{t}$ plus 2. Corresponding $p$-values in parenthesis. The time-varying long run money demand equation considered is $\left(m_{t}-p_{t}\right)=\beta_{0}+\beta_{t}^{y} y_{t}+\boldsymbol{\beta}_{t}^{X} \mathbf{X}_{t}$, where: $\left(m_{t}-p_{t}\right)=$ log-real balances, $y_{t}=$ log-real income, $\Delta u_{t}=$ y-o-y differences of unemployment rate, $q_{t}=$ log-price to earnings ratio, $q_{t}^{*}=\mathrm{US} \log$-price to earnings ratio, $\ell_{t}=$ long-term interest rate, $o_{t}=$ own rate, $\pi_{t}=\mathrm{q}-\mathrm{o}-\mathrm{q}$ inflation rate.

Table 6: Trace test-statistics FOR DEtermining the COINTEgRation RANK $r$.

\begin{tabular}{lccccc}
\hline \hline$k-r$ & $r$ & Eig & Trace & $c_{95 \%}$ & $p$-val \\
\hline 6 & 0 & 0.422 & 180.842 & 95.514 & 0.00 \\
5 & 1 & 0.412 & 118.380 & 69.611 & 0.00 \\
4 & 2 & 0.235 & 57.781 & 47.707 & 0.00 \\
3 & 3 & 0.134 & 27.206 & 29.804 & 0.10 \\
2 & 4 & 0.090 & 10.856 & 15.408 & 0.22 \\
1 & 5 & 0.001 & 0.164 & 3.841 & 0.69 \\
\hline \hline
\end{tabular}

For a given value of the cointegration rank $r$ and given $k=6$, the number of variables, $k-r$ represents the number of common trends, the third (Eig) and fourth (Trace) columns report the largest eigenvalue and the Johansen Trace statistics, the fifth $\left(c_{95 \%}\right)$ and sixth $(p$-val) column report the $95 \%$ critical values and the corresponding $p$-values for test.

Table 7: Estimates of the LOng RUn structure - $\widehat{\boldsymbol{\beta}}^{\prime}$.

\begin{tabular}{|c|c|c|c|c|c|c|}
\hline & $\left(m_{t}-p_{t}\right)$ & $y_{t}$ & $\Delta u_{t}$ & $\left(q_{t}-q_{t}^{*}\right)$ & $\left(\ell_{t}-o_{t}\right)$ & $\pi_{t}$ \\
\hline$\widehat{\boldsymbol{\beta}}_{1}$ & $\begin{array}{l}1.000 \\
{[N A]}\end{array}$ & $\begin{array}{l}-1.893 \\
{[-38.345]}\end{array}$ & $\begin{array}{l}-14.478 \\
{[-16.613]}\end{array}$ & $\begin{array}{l}-2.052 \\
{[-11.477]}\end{array}$ & $\begin{array}{l}0.000 \\
{[N A]}\end{array}$ & $\begin{array}{l}0.000 \\
{[N A]}\end{array}$ \\
\hline$\widehat{\boldsymbol{\beta}}_{2}$ & $\begin{array}{l}0.000 \\
{[N A]}\end{array}$ & $\begin{array}{l}0.000 \\
{[N A]}\end{array}$ & $\begin{array}{l}1.000 \\
{[N A]}\end{array}$ & $\begin{array}{l}0.000 \\
{[N A]}\end{array}$ & $\begin{array}{l}-0.099 \\
{[-3.192]}\end{array}$ & $\begin{array}{l}0.000 \\
{[N A]}\end{array}$ \\
\hline$\widehat{\boldsymbol{\beta}}_{3}$ & $\begin{array}{l}0.000 \\
{[N A]}\end{array}$ & $\begin{array}{c}0.000 \\
{[N A]}\end{array}$ & $\begin{array}{l}0.000 \\
{[N A]}\end{array}$ & $\begin{array}{l}0.000 \\
{[N A]}\end{array}$ & $\begin{array}{l}1.000 \\
{[N A]}\end{array}$ & $\begin{array}{c}-0.560 \\
{[-10.758]}\end{array}$ \\
\hline
\end{tabular}

Estimated long run coefficients $\widehat{\boldsymbol{\beta}}$ in the identified model, $t$-statistics in parenthesis, where: $\left(m_{t}-p_{t}\right)=\log$-real balances, $y_{t}=$ log-real income, $\Delta u_{t}=$ y-o-y differences of unemployment rate, $q_{t}=\log$-price to earnings ratio, $q_{t}^{*}=\mathrm{US} \log$-price to earnings ratio, $\ell_{t}=$ long-term interest rate, $o_{t}=$ own rate, $\pi_{t}=\mathrm{q}-\mathrm{o}-\mathrm{q}$ inflation rate. 
Table 8: Estimates OF THE SHORT RUN DYNAMiCS - $\widehat{\boldsymbol{\alpha}}$.

\begin{tabular}{|c|c|c|c|c|c|c|}
\hline & \multicolumn{3}{|c|}{ (a) } & \multicolumn{3}{|c|}{ (b) } \\
\hline & $\widehat{\boldsymbol{\alpha}}_{1}$ & $\widehat{\boldsymbol{\alpha}}_{2}$ & $\widehat{\boldsymbol{\alpha}}_{3}$ & $\widehat{\boldsymbol{\alpha}}_{1}$ & $\widehat{\boldsymbol{\alpha}}_{2}$ & $\widehat{\boldsymbol{\alpha}}_{3}$ \\
\hline$\Delta\left(m_{t}-p_{t}\right)$ & $\begin{array}{l}-0.002 \\
{[-0.157]}\end{array}$ & $\begin{array}{l}-0.441 \\
{[-2.257]}\end{array}$ & $\begin{array}{l}-0.265 \\
{[-3.261]}\end{array}$ & $\begin{array}{l}-0.001 \\
{[-5.107]}\end{array}$ & $\begin{array}{l}-0.447 \\
{[-4.033]}\end{array}$ & $\begin{array}{l}-0.246 \\
{[-3.292]}\end{array}$ \\
\hline$\Delta y_{t}$ & $\begin{array}{l}-0.047 \\
{[-4.025]}\end{array}$ & $\begin{array}{l}-0.588 \\
{[-4.073]}\end{array}$ & $\begin{array}{c}0.068 \\
{[1.135]}\end{array}$ & $\begin{array}{l}-0.042 \\
{[-4.247]}\end{array}$ & $\begin{array}{l}-0.607 \\
{[-5.160]}\end{array}$ & $\begin{array}{c}0.075 \\
{[1.261]}\end{array}$ \\
\hline$\Delta \Delta u_{t}$ & $\begin{array}{c}0.013 \\
{[4.653]}\end{array}$ & $\begin{array}{c}0.000 \\
{[0.003]}\end{array}$ & $\begin{array}{l}-0.002 \\
{[-0.131]}\end{array}$ & $\begin{array}{l}0.013 \\
{[4.451]}\end{array}$ & $\begin{array}{l}-0.003 \\
{[-0.086]}\end{array}$ & {$\left[\begin{array}{c}0.004 \\
{[-0.317}\end{array}\right]$} \\
\hline$\Delta\left(q_{t}-q_{t}^{*}\right)$ & $\begin{array}{l}0.220 \\
{[6.029]}\end{array}$ & $\begin{array}{l}2.811 \\
{[6.205]}\end{array}$ & $\begin{array}{l}0.469 \\
{[2.492]}\end{array}$ & $\begin{array}{c}0.199 \\
{[5.600]}\end{array}$ & $\begin{array}{l}2.625 \\
{[5.857]}\end{array}$ & $\begin{array}{l}0.366 \\
{[2.114]}\end{array}$ \\
\hline$\Delta\left(\ell_{t}-o_{t}\right)$ & $\begin{array}{c}0.007 \\
{[0.896]}\end{array}$ & $\begin{array}{c}0.166 \\
{[1.654]}\end{array}$ & $\begin{array}{l}-0.082 \\
{[-1.970]}\end{array}$ & $\begin{array}{l}-0.000 \\
{[-2.023]}\end{array}$ & $\begin{array}{c}0.039 \\
{[0.741]}\end{array}$ & $\begin{array}{l}-0.085 \\
{[-2.459]}\end{array}$ \\
\hline$\Delta \pi_{t}$ & $\begin{array}{l}0.055 \\
{[2.167]}\end{array}$ & $\begin{array}{l}0.404 \\
{[1.285]}\end{array}$ & $\begin{array}{l}0.403 \\
{[3.084]}\end{array}$ & $\begin{array}{l}0.038 \\
{[1.860]}\end{array}$ & $\begin{array}{l}0.141 \\
{[0.563]}\end{array}$ & $\begin{array}{l}0.345 \\
{[2.721]}\end{array}$ \\
\hline
\end{tabular}

Estimated short-run coefficients $\widehat{\boldsymbol{\alpha}}$ in the identified model, $t$-statistics in parenthesis, where: $\left(m_{t}-p_{t}\right)=$ log-real balances, $y_{t}=$ log-real income, $\Delta u_{t}=\mathrm{y}$-o-y differences of unemployment rate, $q_{t}=$ log-price to earnings ratio, $q_{t}^{*}=\mathrm{US}$ log-price to earnings ratio, $\ell_{t}=$ long-term interest rate, $o_{t}=$ own rate, $\pi_{t}=\mathrm{q}-\mathrm{O}-\mathrm{q}$ inflation rate. Left panel (a) represents estimates obtained by leaving each term in the CVAR short-run dynamics, whereas right panel (b) reports the same estimates when eliminating the non-significant coefficients $\widehat{\boldsymbol{\Gamma}}_{j}$ in equation (8). 
Table 9: IMPLICATIONS FOR FINANCIAL STABILITY.

\begin{tabular}{|c|c|c|c|c|c|c|c|}
\hline $\operatorname{Prob}\left(B_{t}=1\right)$ & model I & model II & model III & 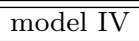 & model V & model VI & "model VII \\
\hline$\left(l_{t-1}-y_{t-1}\right)$ & $\begin{array}{l}1.604 \\
{[1.961]}\end{array}$ & - & $\begin{array}{c}1.863 \\
{[1.879]}\end{array}$ & $\begin{array}{l}2.145 \\
{[1.905]}\end{array}$ & - & $\begin{array}{l}2.974 \\
{[1.412]}\end{array}$ & - \\
\hline$\left(l_{t-2}-y_{t-2}\right)$ & $\begin{array}{l}-1.458 \\
{[-1.937]}\end{array}$ & - & $\begin{array}{l}-1.703 \\
{[-1.840]}\end{array}$ & $\begin{array}{l}-1.974 \\
{[-1.888]}\end{array}$ & - & $\begin{array}{l}-2.779 \\
{[-1.400]}\end{array}$ & - \\
\hline$\left(\ell_{t-1}-o_{t-1}\right)$ & - & $\begin{array}{l}0.825 \\
{[0.775]}\end{array}$ & $\begin{array}{l}2.602 \\
{[1.313]}\end{array}$ & - & $\begin{array}{l}1.645 \\
{[1.139]}\end{array}$ & $\begin{array}{c}6.418 \\
{[0.868]}\end{array}$ & - \\
\hline$\left(\ell_{t-2}-o_{t-2}\right)$ & - & $\begin{array}{l}-2.154 \\
{[-1.752]}\end{array}$ & $\begin{array}{l}-2.852 \\
{[-1.232]}\end{array}$ & - & $\begin{array}{l}-2.906 \\
{[-1.685]}\end{array}$ & $\begin{array}{l}-7.233 \\
{[-0.948]}\end{array}$ & - \\
\hline$\widehat{\eta}_{1, t-1}$ & - & - & - & $\begin{array}{l}2.080 \\
{[2.006]}\end{array}$ & $\begin{array}{l}1.591 \\
{[2.038]}\end{array}$ & $\begin{array}{l}3.116 \\
{[1.488]}\end{array}$ & $\begin{array}{l}1.184 \\
{[2.688]}\end{array}$ \\
\hline$\widehat{\eta}_{1, t-2}$ & - & - & - & $\begin{array}{l}-1.120 \\
{[-1.204]}\end{array}$ & $\begin{array}{l}-0.862 \\
{[-1.133]}\end{array}$ & $\begin{array}{l}-1.523 \\
{[-0.952]}\end{array}$ & $\begin{array}{l}-0.250 \\
{[-0.628]}\end{array}$ \\
\hline $\bar{R}^{2}$ & 0.62 & 0.35 & 0.66 & 0.72 & 0.52 & 0.77 & 0.31 \\
\hline$R^{2}$ & 0.43 & 0.22 & 0.47 & 0.52 & 0.35 & 0.58 & 0.19 \\
\hline QPS & 0.07 & 0.12 & 0.06 & 0.06 & 0.09 & 0.04 & 0.12 \\
\hline \multicolumn{8}{|l|}{$\zeta=0.25$} \\
\hline Good & $92 \%$ & $86 \%$ & $94 \%$ & $97 \%$ & $90 \%$ & $97 \%$ & $88 \%$ \\
\hline $\mathrm{NtS}$ & 0.08 & 0.21 & 0.07 & 0.03 & 0.11 & 0.04 & 0.16 \\
\hline \multicolumn{8}{|l|}{$\zeta=0.35$} \\
\hline Good & $94 \%$ & $92 \%$ & $95 \%$ & $96 \%$ & $90 \%$ & $97 \%$ & $90 \%$ \\
\hline $\mathrm{NtS}$ & 0.06 & 0.06 & 0.05 & 0.02 & 0.11 & 0.02 & 0.12 \\
\hline
\end{tabular}

Probit regressions with dependent variable the binary bust indicator $B_{t}$. The estimation period is 1985:Q4-2008:Q4, i.e. $T=93$. In all models we include a constant. The explanatory variables are: lags of the spread $\left(\ell_{t-h}-o_{t-h}\right)$, lags of the estimated monetary overhang $\widehat{\eta}_{1, t-h}$ as defined in equation (9), lags of the loans-to-income ratio $\left(l_{t-h}-y_{t-h}\right)$. For each estimated model we report the maximum likelihood value of the estimated coefficients with their $t$-statistics in parenthesis, the McFadden $\bar{R}^{2}$ and the $R^{2}$ as computed in Estrella and Mishkin (1998), and the quadratic probability score (QPS) as defined in Gerdesmeier et al. (2010). The percentages of good signals and the noise-to-signal ratio $(N t S)$ are computed with a threshold $\zeta=0.25$ and 0.35 (the percentage of bad signals is equal to $100 \%$-percentage of good signals). 
Table 10: IMPLICATIONS FOR PRICE STABILITY.

\begin{tabular}{|c|c|c|c|}
\hline$\pi_{t}$ & model I & model II & model III \\
\hline$\pi_{t-1}$ & $\begin{array}{c}0.396 \\
{[4.077]}\end{array}$ & $\begin{array}{c}0.394 \\
{[4.165]}\end{array}$ & $\begin{array}{c}0.396 \\
{[4.077]}\end{array}$ \\
\hline$\pi_{t-2}$ & $\begin{array}{c}0.275 \\
{[2.586]}\end{array}$ & $\begin{array}{c}0.295 \\
{[2.897]}\end{array}$ & $\begin{array}{c}0.275 \\
{[2.586]}\end{array}$ \\
\hline$\pi_{t-3}$ & $\begin{array}{c}0.022 \\
{[0.201]}\end{array}$ & $\begin{array}{c}0.050 \\
{[0.488]}\end{array}$ & $\begin{array}{c}0.022 \\
{[0.201]}\end{array}$ \\
\hline$\pi_{t-4}$ & $\begin{array}{c}0.269 \\
{[2.742]}\end{array}$ & $\begin{array}{c}0.213 \\
{[2.324]}\end{array}$ & $\begin{array}{c}0.269 \\
{[2.742]}\end{array}$ \\
\hline$\widehat{\eta}_{1, t-1}$ & - & $\begin{array}{c}0.018 \\
{[0.724]}\end{array}$ & $\begin{array}{c}0.015 \\
{[0.548]}\end{array}$ \\
\hline$\widehat{\eta}_{1, t-2}$ & - & $\begin{array}{l}-0.039 \\
{[-1.144]}\end{array}$ & $\begin{array}{l}-0.037 \\
{[-1.047]}\end{array}$ \\
\hline$\widehat{\eta}_{1, t-3}$ & - & $\begin{array}{c}0.081 \\
{[2.356]}\end{array}$ & $\begin{array}{c}0.075 \\
{[2.144]}\end{array}$ \\
\hline$\widehat{\eta}_{1, t-4}$ & - & $\begin{array}{l}-0.028 \\
{[-1.148]}\end{array}$ & $\begin{array}{l}-0.020 \\
{[-0.805]}\end{array}$ \\
\hline$\Delta y_{t-1}$ & - & - & $\begin{array}{c}0.029 \\
{[0.142]}\end{array}$ \\
\hline$\Delta y_{t-2}$ & - & - & $\begin{array}{c}0.279 \\
{[1.309]}\end{array}$ \\
\hline$\Delta y_{t-3}$ & - & - & $\begin{array}{l}-0.224 \\
{[-1.030]}\end{array}$ \\
\hline$\Delta y_{t-4}$ & - & - & $\begin{array}{c}0.191 \\
{[0.862]}\end{array}$ \\
\hline $\operatorname{adj} .-R^{2}$ & 0.96 & 0.96 & 0.96 \\
\hline
\end{tabular}

Linear regressions with as dependent variable is the $\mathrm{q}-\mathrm{o}-\mathrm{q}$ inflation rate $\pi_{t}$. The estimation period is 1980:Q1-2008:Q4, i.e. $T=116$. In all models we include a constant. The explanatory variables are: lagged q-o-q inflation rate $\pi_{t-h}$, lags of the estimated monetary overhang $\widehat{\eta}_{1, t-h}$ as defined in equation (9), lagged q-o-q income growth rate $\Delta y_{t-h}$. For each estimated model we report the least squares estimates of the coefficients with their $t$-statistics in parenthesis and the adjusted $R^{2}$.

Table 11: Prediction COMPARISON.

\begin{tabular}{llccc}
\hline \hline Sample & & Our model & De Bondt (2010) & De Santis et al. (2012) \\
\hline & & & & \\
1980:Q1-2008:Q4 & $\Delta_{4}\left(m_{t}-p_{t}\right)$ & 1.096 & 1.222 & 1.117 \\
& $\Delta_{4} y_{t}$ & 0.723 & 0.853 & 0.771 \\
& & & \\
2009:Q1-2010:Q4 & $\Delta_{4}\left(m_{t}-p_{t}\right)$ & 0.569 & 1.147 & 2.055 \\
& $\Delta_{4} y_{t}$ & 2.418 & 2.674 & 2.103 \\
& & & \\
\hline
\end{tabular}

Root mean squared errors when comparing the actual path of annual real money and income growth with the conditional expectations obtained from our model (see equation (9)), and De Bondt (2010) and De Santis et al. (2012) specifications. Results for 1980:Q1-2008:Q4 are in-sample estimates, results for 2009:Q1-2010:Q4 are out-of-sample one-step-ahead predictions. 
Figure 1: Money Growth AND INFLATion in the EURo AREA.

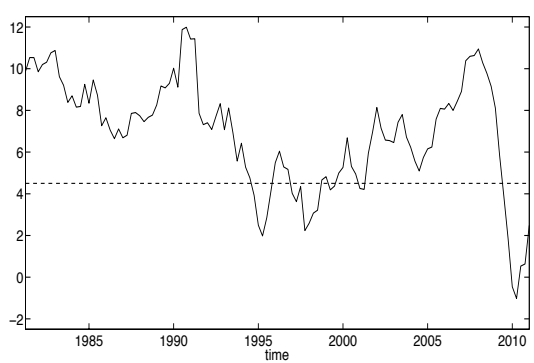

(a) Money growth $100 \Delta_{4}\left(\log M_{t}\right)$.

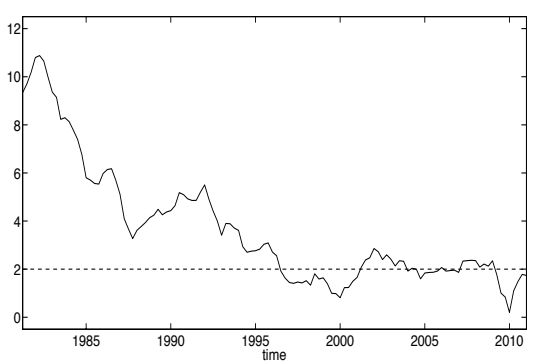

(b) Inflation $100 \Delta_{4}\left(\log P_{t}\right)$.

Solid lines: percentage annualized growth rates of nominal M3 (left) and GDP deflator (right); dashed lines: $4.5 \%$ reference value for $\mathrm{M} 3$ and $2 \%$ target value for inflation. 
Figure 2: CoIntegration RESIDUAL IN the Literature.

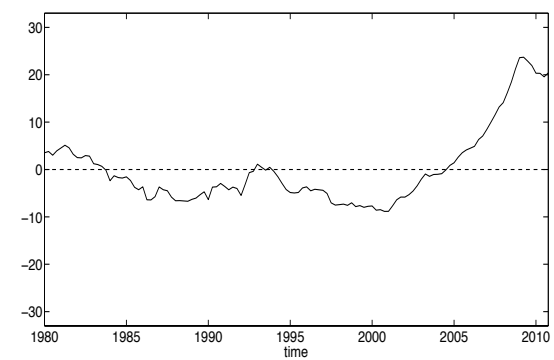

(a) Calza et al. (2001)

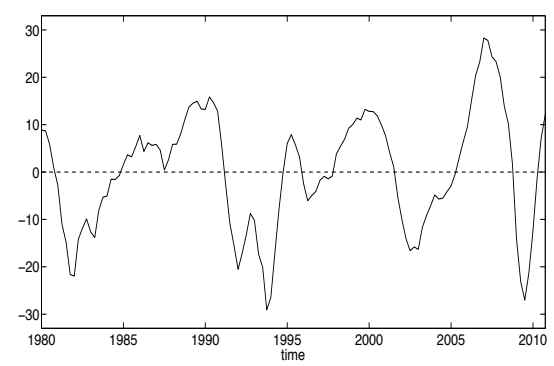

(c) De Bondt (2010)

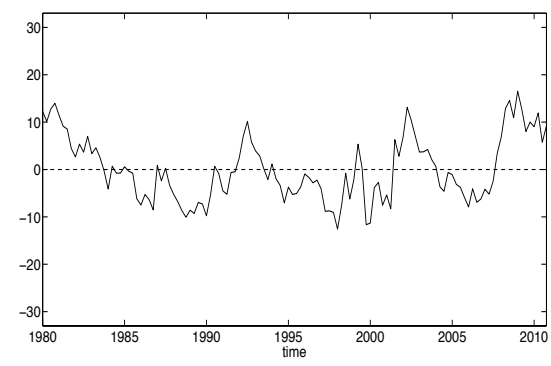

(b) De Santis et al. (2012)

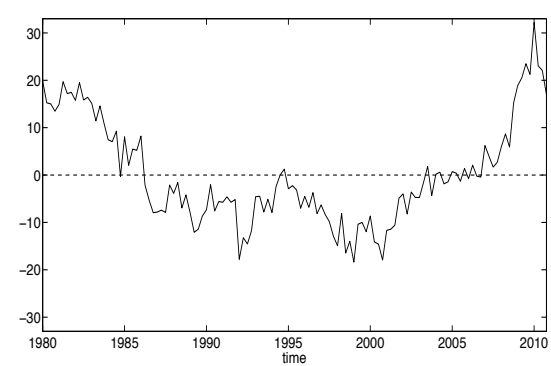

(d) Dreger and Wolters (2010b)

The disequilibrium (residual) is computed as $\left(m_{t}-p_{t}\right)-\widehat{\beta}^{y} y_{t}+\widehat{\boldsymbol{\beta}}^{\mathbf{X}} \mathbf{X}_{t}$, where the estimated coefficients are given in the original papers. Values are re-scaled to have zero mean over the sample period. 
Figure 3: Cointegration Residual in Barigozzi And Conti SPECification.

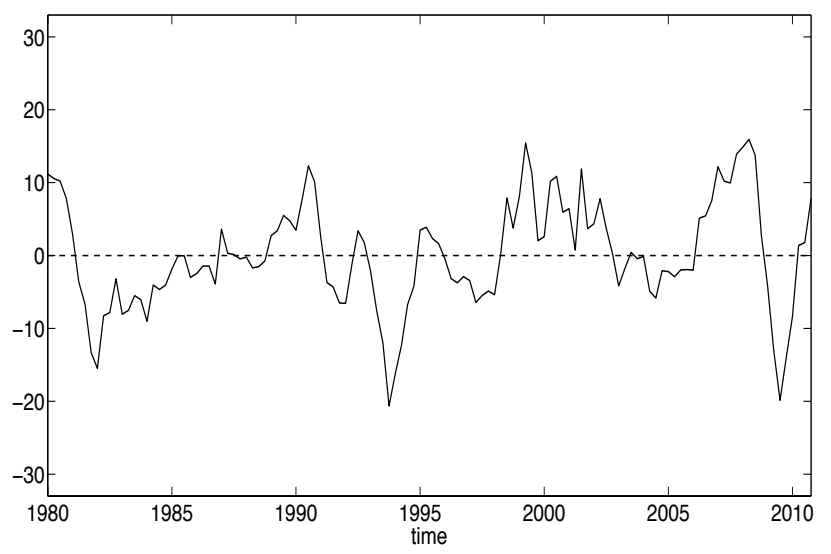

The disequilibrium (residual) is computed as $\widehat{\eta}_{1, t}=\left(m_{t}-p_{t}\right)-1.89 y_{t}-14.48 \Delta u_{t}-2.05\left(q_{t}-q_{t}^{*}\right)$. Values are re-scaled to have zero mean over the sample period. 
Figure 4: Generalized impulse Responses to the money disequilibrium.

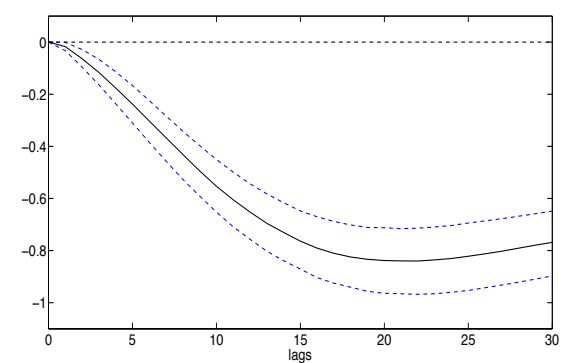

(a) Response of $\left(m_{t}-p_{t}\right)$.

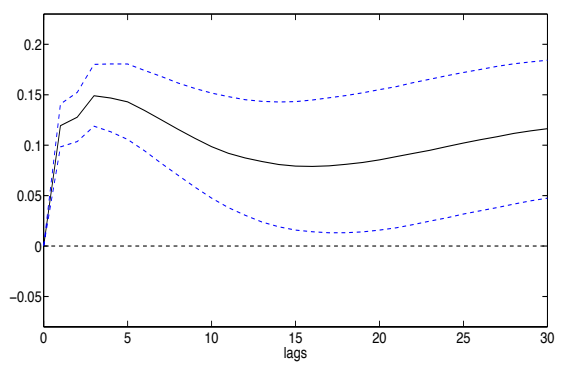

(b) Response of $\pi_{t}$.

Solid lines: generalized impulse responses of real balances $\left(m_{t}-p_{t}\right)$ and inflation $\pi_{t}$ to the estimated cointegration residual $\widehat{\eta}_{1, t}$ obtained from a VAR as in King et al. (1991). Dashed lines: 68\% confidence intervals obtained with 1000 Monte Carlo replications. 
Figure 5: MONEY DISEQUILIBRIUM AS LEADING INDICATOR OF STOCK MARKETS BUSTS.

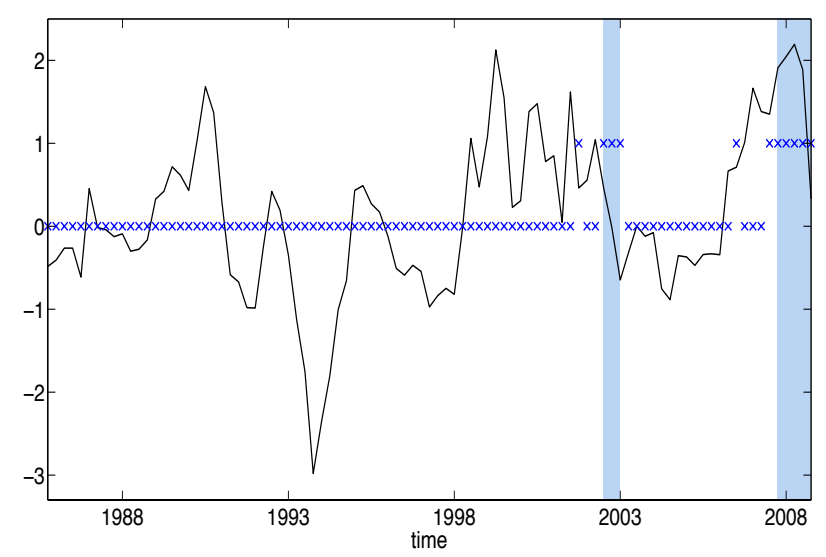

Solid line: estimated cointegration residual of the long-run money demand equation, $\widehat{\eta}_{1, t}$; crosses: predicted signals from the probit model VI in table 9 when $\zeta=0.25$; shaded areas: stock market busts corresponding to $B_{t}=1$ as defined in equation (10). The cointegration residual is standardized to have zero mean and unit variance over the sample period. 
Figure 6: Predictions of REAL M3 AND GDP GROWTH RATES.

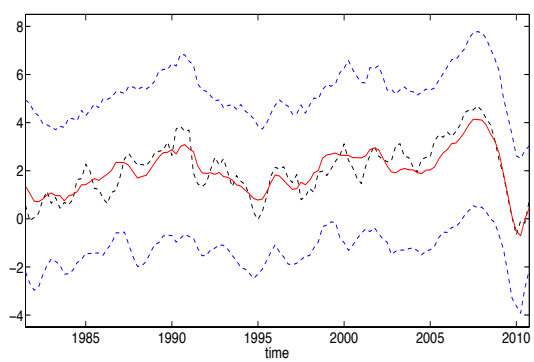

(a) Real M3 growth $100 \Delta_{4}\left(m_{t}-p_{t}\right)$

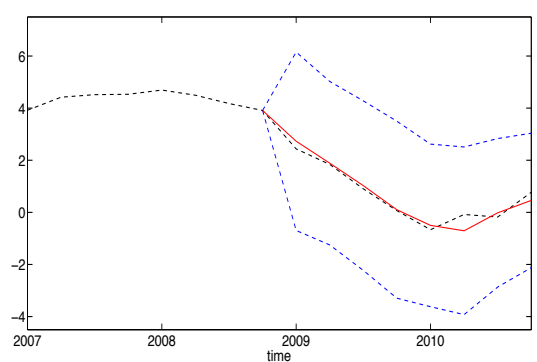

(c) Real M3 growth $100 \Delta_{4}\left(m_{t}-p_{t}\right)$

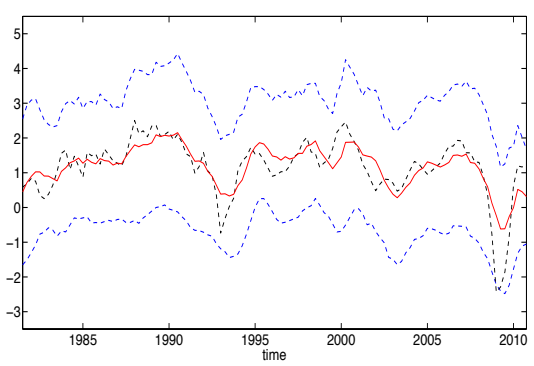

(b) GDP growth $100 \Delta_{4} Y_{t}$

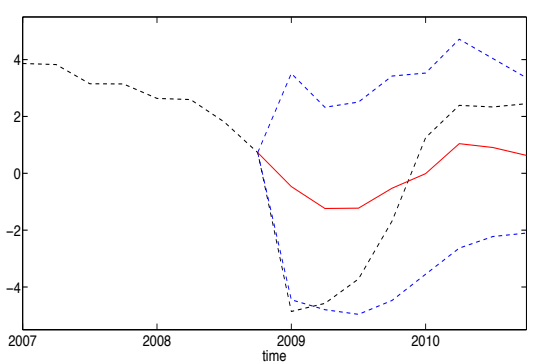

(d) GDP growth $100 \Delta_{4} Y_{t}$

Dashed line: percentage annualized growth rates of observed series; solid line: in-sample conditional expectations for the period 1983:Q1-2008:Q4 (top panel) and out-sample one-step-ahead predictions for the period 2009:Q1-2010:Q4 (bottom panel); 90\% confidence intervals are also shown. For details see equation 11. 